\title{
Evaluation of New Properties of Calcined Magnetite Doped with Zinc and Lanthanum Nanoparticles Prepared in Oxygen and Nitrogen Atmospheres
}

Mohamed A. Zayed

Cairo University

Mahmoud F. Mubarak ( $\square$ fathy8753@yahoo.com )

EPRI: Egyptian Petroleum Research Institute

Gehad M. Abdel-maksoud

Cairo University

\section{Research Article}

Keywords: Calcinated Zinc-La magnetite, Co-precipitation, Magnetic properties, Optical properties,

Photoluminescence

Posted Date: May 5th, 2021

DOl: https://doi.org/10.21203/rs.3.rs-479434/v1

License: (c) (i) This work is licensed under a Creative Commons Attribution 4.0 International License.

Read Full License 


\section{Abstract}

The aim of the present research is the preparation of magnetite nanoparticles doped with $\mathrm{Zn}$ and La of the general formula $\mathrm{ZnLa}(\mathrm{x}) \mathrm{Fe}_{(3-\mathrm{x})} \mathrm{O}_{4}$ where $\mathrm{x}=0.0,0.1,0.15,0.2,0.25$ and 0.3 ; which were prepared via co-precipitation method, separated and calcined at $800^{\circ} \mathrm{C}$ under oxygen and nitrogen atmospheres. The stoichiometric ratios of the elements in the given general formula had been proved and confirmed by elemental analyses using XRF. Various techniqueshave been used to analyze the prepared nanoparticles. X-ray diffraction (XRD) confirmed the formation of one single phase of nanoparticles components with average crystalline size ranged from 6 to $9 \mathrm{~nm}$ at oxygen atmosphere and from 6 to 8 at nitrogen atmosphere.These size values had been calculated by Debye-Scherrer equation. The optical properties carried out by Cary Eclipse fluorescence spectrophotometer.The morphology of the prepared magnetite nanoparticles was studied using field emission scanning electron microscope (FE-SEM) and highresolution transmission electron microscope (HRTEM). Optical properties were demonstrated by UVvisible-NIR spectrophotometer. The high absorbance values of $\mathrm{Zn} \mathrm{La}(x) \mathrm{Fe}_{(3-x)} \mathrm{O}_{4}$ were found to 80-97 and $80-99 \%$ in the visible wavelength range of $400-800 \mathrm{~nm}$ for the prepared samples in presence of $\mathrm{O}_{2}$ and $\mathrm{N}_{2}$ gas at room temperature, respectively. These proved the lower values of energy band gap in both conditions. The lowering of energy band gap of $1.89 \mathrm{eV}$ for nanoparticles prepared in $\mathrm{O}_{2}$ gas and $1.78 \mathrm{eV}$ for prepared in $\mathrm{N}_{2}$ gas in most samples may be attributed to incorporation of $\mathrm{Zn}$ cation. These results are confirmed by photo luminscence spectra (PL) measurements of the prepared samples. Magnetic properties of the given samples obtained from vibrating sample magnetometer (VSM);showed that most of these samples exhibited almost superparamagnetic behavior. These magnetic values (32.87 and 24.79 emu $/ \mathrm{g}$ ) infer super saturation magnetization of the given samples prepared in $\mathrm{O}_{2}$ and $\mathrm{N}_{2}$ gas at room temperature, respectively. Examination of the magnetic properties revealed decrease in saturation magnetization with increasing La ion concentrations incorporation up to $x=0.3$. The evaluated magnetic and optical properties of the novel prepared $\mathrm{ZnLa}(x) \mathrm{Fe}_{(3-x)} \mathrm{O}_{4}$ nano-materials revealed their possible use in different industrial fields like bio-applications, in electronic components, cosmetics, antibacterial agents, and in solar cells. The antibacterial activity study of the prepared NPs revealed them highly efficient against different kinds of bacteria that increase with increase of La \% doped in their entity.

\section{Introduction}

Nanotechnology is exactly meant any technology that carried out in the nanoscale and has many applications in the real world, where the size of the atoms for the matter is about 1 to $100 \mathrm{~nm}$ as mentioned by I. Amato, et.al (1999)[1]. The peerless physical and chemical properties of nanomaterials have a profound effect by B. Bhushan (2015)[2] on commercial applications and for novel performance that benefits societyNanomaterials have distinct physicochemical and biological properties. Particularly, their small size and diffusion abilities, shape, chemical composition, surface structure and charge, aggregation and agglomeration, and solubility can affect their interactions with biomolecules, cells, and organs. So, it can get into the human body in various ways, such as skin penetration, inhalation, or injection by Rahmandoust, M. et.al (2019) [3].Magnetic nanoparticles present many applications in 
biomedicine which have been evaluated by S. Laurent, et.al (2008)[4] in vitro and in animal experiments.Compared to non-metallic nano formulations of similar sizes, the higher density Metallic nano particles are more readily taken up by cells, providing a benefit for cancer vaccination strategies as studied by Barnaby, et. al (2014) [5].Iron oxide nanoparticles (IONPs) include many attributes of high magnetic saturation, stability, biocompatibility, and interactive functions at the surface. The surface of IONPs could beadjusted by organic materials or inorganic materials, such as polymers, biomolecules, silica, metals, and others that improve from its properties by Wu, et. al (2015) [6].Laurent, et. al (2011) [7] suggested bio-applications based on magnetic nanoparticles (NPs) have received considerable attention because NPs offer unique advantages over other materials. Magnetite is a spin-polarized, $\mathrm{Fe}^{2+}-\mathrm{Fe}^{3+}$ mixed-valence metal with a DC conductivity at $23^{\circ} \mathrm{C}$ of about $0.1 \%$ that of Cu metal. Its crystals appear black and absorb throughout the UV-VIS-IR spectrum as indicating by Tang, et. al (2003)[8]. A variety of synthetic methods such as co-precipitation are given by Rao, et. al (2018)[9], while thermal decomposition are given by Ibrahim, et. al (2018)[10], and hydrothermal and solvo thermal syntheses, sol-gel synthesis are given by de Mello, et. al (2019)[11].The variety of magnetic materials can be formed from iron atom which has four unpaired electrons in its $3 \mathrm{~d}$ orbital. The magnetic behavior of the materials can be classified into six types, depending on the particular response of the materials in the presence of a magnetic field. The materials are categorized bySpaldin, et. al (2010)[12]; into diamagnetic, paramagnetic, ferromagnetic, antiferromagnetic and superparamagnetic, on the basis of net magnetic moment of their atoms.Due to the advanced propertiesof nanomaterials, it was widely used by $\mathrm{Ma}$, et. al (2010)[13] and Nel, et. al (2006)[14] in electronic components, cosmetics, antibacterial agents, and solar cells. During the last few decades there has been an increasing interest in utilizing nanoparticles and nanotechnology in cancer diagnosis and treatment by Barkalina, et. al (2014)[15] and Hofmann, et. al (2015)[16].M. A. Zayed, et.al (2016) [17]prepared herein, novel ferrofluid nanocomposites $\mathrm{xFe}_{2} \mathrm{O}_{3} /(1$ $-x) \mathrm{Fe}_{3} \mathrm{O}_{4}$ with different ratios of $x(0.0 \leq x \leq 1.0)$ from magnetite and hematite nanoparticles (NPs) were prepared via a sonochemical method, for hyperthermia purposes. Various analytical and characterization techniques have been used to analyze and characterize the prepared ferrofluid nanocomposites.M. A. Zayed, et.al (2016)[18] were used various analytical techniques to analyze and characterize the ferrous/ ferric constituents of the prepared ferrofluid nanocomposites $x_{F_{2}} \mathrm{O}_{3} /(1-x) \mathrm{Fe}_{3} \mathrm{O}_{4}$ with different ratio $\mathrm{x}$ $(0.0 \leq x \leq 1.0)$, from magnetite and hematite nanoparticles (NPS). These ferrofluid composites were prepared via the sonochemical method, for the first time, for hyperthermia purposes.P. M. Zélis et al. (2013)[19] obtained Cubic-like shaped $\mathrm{Zn}_{x} \mathrm{Fe}_{3-\mathrm{x}} \mathrm{O}_{4}$ particles with crystallite mean sizes $\mathrm{D}$ between 15 and $117 \mathrm{~nm}$ by co-precipitation.Amir, M., et al. (2015)[20] synthesized the single spinel phase nano-structured particles of $\mathrm{FeB}_{\mathrm{x}} \mathrm{Fe}_{2-\mathrm{x}} \mathrm{O}_{4}(\mathrm{x}=0.1,0.2,0.3,0.4$ and 0.5$)$ by the glycol-thermal method and the effect of $\mathrm{B}^{3+}$ substitution on structural and dielectric properties of $\mathrm{Fe}_{3} \mathrm{O}_{4}$ were studied by L. Hu, et.al (2012)[21] investigated the effect of cobalt substitution on the size evolution, crystal structure, and magnetic properties of $\mathrm{Fe}_{3} \mathrm{O}_{4}$ nanoparticles. Mono-disperse $\mathrm{Co}_{x} \mathrm{Fe}_{3-\mathrm{x}} \mathrm{O}_{4}$ nanoparticles were prepared, using a onestep method, by the direct heating process of iron (III) and cobalt (II) acetylacetonates in a high-boilingpoint inert organic solvent.The magnetic moments of magnetite nanoparticles were dramatically enhanced by J. Byrne, et.al (2014)[22]through the addition of zinc in a microbiologically driven synthesis 
procedure.Super-paramagnetic iron oxide nanoparticles (SPIONs) had been approved by R. Hergt, et.al (2006)[23] for clinical use due to their salient super-paramagnetic properties and low toxicity. $\mathrm{Zn}^{2+}$ doped SPIONs possess significantly higher magnetic susceptibility than that of conventional SPIONs. Here we evaluated the potential toxicity of $\mathrm{Zn}^{2+}$ doped $\mathrm{Fe}_{3} \mathrm{O}_{4}$ nanoparticles $\left(\mathrm{Zn}_{0} \cdot 4 \mathrm{Fe}_{2} \cdot 6 \mathrm{O}_{4} \mathrm{NPs}\right)$ in the liver and kidney of mice after repeated intragastric administration for 30 days.E. Fantechi et al. (2015)[24] found that magnetite nanoparticles (NPs) are widely carried out for biomedical applications, particularly as contrast agents for Magnetic Resonance Imaging and as heat mediators in Magnetic Fluid Hyperthermia.Y. Zhang, et.al (2002)[25]stated that, Superparamagnetic magnetite nanoparticles were surface-modified with poly (ethylene glycol) (PEG) and folic acid, respectively, to improve their intracellular uptake and ability to target specific cells.A progress report by Q. Pankhurst, et.al (2009)[26] shows that, a selection of scientific, technological and commercialadvances in the biomedical applications of magnetic nanoparticles since 2003.G. R. J. Allard.et al. (2015)[27] had been prepared the nanoparticles via the co-precipitation route and masked with 3-phosphonopropionic acid (3-PPA).M.

Bloemen et.al, (2014)[28]reported that, rare earth atoms exhibit several interesting properties, for example, large magnetic moments and luminescence. Introducing these atoms into a different matrix could lead to a material that showed multiple interesting effects. M. T. FARID, et. al (2015) [29]studied the effect of neodymium ( $\mathrm{Nd}$ ) contents on the structural, electrical and dielectric properties of Nickel cobalt ferrites in the ferrite series $\mathrm{Ni}_{x} \mathrm{CO}_{1-\mathrm{x}} \mathrm{Nd}_{y} \mathrm{Fe}_{2-y} \mathrm{O}_{4}(\mathrm{x}=0.00,0.20,0.40,0.60,0.80,1.0$ and $\mathrm{y}=0.00,0.02,0.04,0.06,0.08$, 0.1 ). This series was synthesized by the sol-gel method.A series of $\mathrm{Gd}^{3+}$ doped nano-crystalline Coferrites $\mathrm{CoGd}_{x} \mathrm{Fe}_{2-\mathrm{x}} \mathrm{O}_{4}(\mathrm{x}=0.0$ to 0.1$)$ had been prepared by E. Pervaiz, et.al (2013)[30] using sol-gel auto combustion technique.La- and $\mathrm{Ni}$-doped $\mathrm{Fe}_{3} \mathrm{O}_{4}$ nanocomposite particles with a high saturation magnetization were prepared by MA, J.et.al (2009)[31] via a homogeneous precipitation method in aqueous solutions.Fe-doped $\mathrm{La}_{0.77} \mathrm{Sr}_{0.23} \mathrm{Mn}_{1}$ - $\mathrm{Fe}_{\mathrm{y}} \mathrm{O}_{3}$ nanoparticles had been synthesized byShlapa, et. al (2016) [32] using the sol-gel method.B. Balusamy, et. al (2012)[33] presented study to evaluated the bacterial toxicity of lanthanum oxide micron and nano-sized particles using shake flask method against gram-positive (Staphylococcus aureus) and gram-negative (Escherichia coli, Pseudomonas aeruginosa) bacteria.It was speculated that lanthanum oxide produced this effect by interacting with the grampositive bacterial cell wall. Furthermore, lanthanum oxide bulk particles were found to enhance the pyrocyanin pigment production in Pseudomonas aeruginosa.

In the present study, an composite has been made to synthesis La3+ doped $\mathrm{ZnFe} 2 \mathrm{O} 4$ nanoparticles by the two-step sol gel method. Here, we report the synthesis and characterization of $\mathrm{ZnFe}_{2}-\mathrm{xLaxO}_{4}$ through the sol-gel method. Besides, several experiments were performed in order to investigate the chracstric future of prepared composite that include XRD, XRF, TEM ,FESEM and FTIR analysis. The antibacterial activity study of the prepared NPs against different kinds of bacteria studied with varying the La \% doped in the $\mathrm{ZnFe}_{2}-\mathrm{xLaxO}_{4}$.

\section{Experimental}

\subsection{Materials and reagents}


The initial chemicals Tetra hydrated ferrous chloride $\mathrm{FeCl}_{2} \cdot 4 \mathrm{H}_{2} \mathrm{O}\left(\mathrm{M} \cdot \mathrm{wt}=198.81 \mathrm{~g} \mathrm{~mol}^{-1}\right.$ ) was purchased from Research-Lab fine industries, Zinc acetate dihydrateZn $\left(\mathrm{CH}_{3} \mathrm{COO}\right)_{2} \cdot 2 \mathrm{H}_{2} \mathrm{O}(\mathrm{M}$.wt $=219.50 \mathrm{~g}$ ) was purchased from Oxford lab chem, Hexahydrated ferric chloride $\mathrm{FeCl}_{3} \cdot 6 \mathrm{H}_{2} \mathrm{O}\left(\mathrm{M} \cdot \mathrm{wt}=270.30 \mathrm{~g} \mathrm{~mol}^{-1}\right)$, Sodium hydroxide $\mathrm{NaOH}\left(\mathrm{M} . \mathrm{wt}=40 \mathrm{~g} \mathrm{~mol}^{-1}\right.$ ) and Lanthanum chloride $\mathrm{LaCl}_{3} .7 \mathrm{H}_{2} \mathrm{O}$ (M.wt $=371.37 \mathrm{~g}$ $\left.\mathrm{mol}^{-1}\right)$ was purchased from Alpha chemika. Hydrochloric acid $(\mathrm{HCl})\left(\mathrm{M} \cdot \mathrm{wt}=36.46 \mathrm{~g} \mathrm{~mol}^{-1}\right)$ with purity 30-34 \%, Hydrofluoric acid (HF) was purchased from Adwic, Ethyl alcohol (ethanol) (M.wt $=46.07 \mathrm{~g} \mathrm{~mol}^{-1}$ ) was purchased from International company for SUP and MED industries. The distilled water used in all preparations usually collected from all glass equipment.

\subsubsection{Preparation of $Z n-L a$ doped magnetite nanoparticles}

Aqueous solution of tetra hydrate ferrous chloride $(0.4 \mathrm{M})$, zinc acetate dihydrate $(0.2 \mathrm{M})$ and hexahydrate ferric chloride (0.2 $\mathrm{M})$ was added in 2:1:1 ratio and the same volumes were taken from each solution $(50 \mathrm{~mL})$. After 10 mins of constant stirring, $\mathrm{NaOH}$ was added drop-wise to the mixture with stirring until the suspension becomes homogenous and the $\mathrm{pH}$ of the solution reached 11 , that in presence of oxygen atmosphere $\left(\mathrm{O}_{2}\right)$ once and repeated again in the presence of nitrogen atmosphere, where $\left(\mathrm{N}_{2}\right)$ gas flow (with $99.9 \%$ of purity) for 20 minute. The particles washed with warmed distilled water several times [34]. Then the reaction is kept at $85-90^{\circ} \mathrm{C}$ for 4 hours. The zinc doped magnetite nanoparticles were magnetically collected with the formula $\mathrm{ZnFe}_{3} \mathrm{O}_{4}$, then the aqueous solutions of tetra hydrate ferrous chloride, zinc acetate dihydrate, hexahydrate ferric chloride were mixed by $50 \mathrm{~mL}$ of an aqueous solution of Lanthanum chloride $7 . \mathrm{H}_{2} \mathrm{O}$ for different ratios $(0.1,0.2$, and $0.3 \mathrm{M})$. Also, after 10 mins of constant stirring, $\mathrm{NaOH}$ was added drop-wise to the mixture with stirring until the suspension becomes homogenous and the $\mathrm{pH}$ of the solution reached 11 . The reactions occur also in the presence of oxygen and the same in a nitrogen atmosphere. The filtered particles were washed with warmed distilled water several times. The reaction is kept at $85-90^{\circ} \mathrm{C}$ for 4 hours. Then $\mathrm{Zn}$-La doped magnetite nanoparticles were magnetically collected; which has the proposed formula $\mathrm{ZnLa}(x) \mathrm{Fe}_{(3-x)} \mathrm{O}_{4}$ where, $x=0.0$, $0.1,0.15,0.2,0.25$ and 0.3 . The dried collected precipitates obtained in nitrogen or oxygen atmosphereswere ignited in special crucibles at $800^{\circ} \mathrm{C}$ for two hours. All prepared samples were kept in suitable plastic vials in dry atmosphere desiccators.

\subsubsection{Analyses}

The spectrophotometric measurements of $\mathrm{Fe}^{2+}$ and $\mathrm{Fe}^{3+}$ in nano-materials solutions using selective indicators were carried out using recording Spectrophotometer, UV-Vis range from 150-1100 nm model Unicam UV 300 and quartz cell of $1 \mathrm{~cm}$ optical length was used. Then total iron and zinc determination had been performed using atomic absorption spectrophotometer model AA.6300 SHIMADZU with an airacetylene flame. X-ray diffraction analyses were carried out using (analytical-x' Pertpro with Cuka1 target, $\lambda=1.5404 \AA, 45 \mathrm{kV}, 40 \mathrm{~mA}$, the Netherland) to identify the formation of the samples in pure single phase.Vibrating sample magnetometer (VSM) of (Model DMS 4HF) was used to measure the magnetic behavior of magnetic materials. The morphology of the various materials was disclosed using field 
emission scanning electron microscopy (FE-SEM-QUANTA FEG 250) attached with EDX unit (Energy dispersive X-ray Analyses.HRTEM instrument of Zeiss Sigma 500 VP Analytical FE-SEM Accelerating voltage range 0.2 to $30 \mathrm{kV}$ Variable pressure range: 2-133 Pa was used to characterize the particle size, shape, and grain size and to confirm the lattice parameter variation across the interfaces using selected area electron diffraction (SAED) pattern.

In the present work, the properties of the synthesized magnetic nanoparticles were investigated. The characteristics of the nanocomposites depend upon their crystal sizes, shapes and structures; which were characterized by advanced and sophisticated methods of analyses using different spectroscopic techniques. So, samples were completely analyzed by UV-Vis spectrophotometry and their solid state structures were investigated by XRD, EDX, HTEM and FESEM. The magnetic properties of the prepared materials were determined by means of the magnetic susceptibility and VSM. Thermal gravimetric analysis (TGA) was performed using a SDT Q 600 V20.9 build 20 (TA Instruments) thermo analyzer with a heating rate of $10 \circ \mathrm{C} / \mathrm{min}$, using a $\mathrm{O}_{2}$ at a flow rate of $50 \mathrm{~mL} / \mathrm{min}$. The photoluminescence spectra of the prepared nano compounds were performed using Cary Eclipse Absolute PL Quantum Fluorescence QM-40 Spectrometer and a Ge photodetector coupled to a data acquisition system composed of a microcomputer-controlled SR530 lock-in amplifier. The $350.7 \mathrm{~nm}$ excitation wavelength of a krypton ion laser (Coherent Innova) was used, with the laser output kept at 200 mW.The biological activities nanocomposites had been studied.

\section{3a. Biological anti-bacterial studies}

The antimicrobial activities of the test samples were determined by means of a modified Kirby-Bauer disc diffusion method by BrabuBalusamyet al [35] under standard conditions using Mueller-Hinton agar medium (tested for composition and pH), as described by NCCLS Sakiyanet al 2004[36]. Plates inoculated with filamentous fungi as Aspergillus flavus at $25^{\circ} \mathrm{C}$ for 48 hours; Gram (+) bacteria as Staphylococcus aureus, Bacillus subtilis; Gram (-) bacteria as Escherichia coli, Pseudomonas a aeruginosa they were incubated at $35-37^{\circ} \mathrm{C}$ for $24-48$ hours and yeast as Candida albicans incubated at $30^{\circ} \mathrm{C}$ for $24-48$ hours and, then the diameters of the inhibition zones were measured in millimeter by Mahdavi et al 2013[37].

\section{Results And Discussion}

\subsection{Particle Size distribution and Morphology Effects}

\subsubsection{HR-TEM Comparison}

Lanthanum oxides have low magnetic characters similar to magnesium oxides in nature that coming after magnetite. Lanthanum has flat or cylindrical pipes crystal shape but it is diffused when mixed with magnetite less than $0.2 \%[38]$. Therefore, these shapes increased in size or its diameter when La\% increased from 0.1 to $0.3 \%$ and the La flat shapes become more common than the cylindrical common shape of magnetite and the most common shape of nano-material becomes more flat shape as shwen in 
Fig.1. For zinc in nano-material goes around magnetite and it takes nano-cylindrical or hexagonal together with fluctuation of their crystal shapes. It is also noticed that, the variation of oxygen into nitrogen atmosphere change crystalline structures the doped Zn-magnetite with different ratios of La especially when ignited at $800^{\circ} \mathrm{C}$. At which in nitrogen atmosphere it takes collective cylindrical Nano pipes groups under the effect of its homogeneity with magnetite[39]. In case of oxygen atmosphere (Fig.2) La appear with magnetite as big layers within which magnetite appears as spots; this means that La oxides crystals are homogenized with some magnetite oxides via oxygen - oxygen boding. Generally heating of nano-materials to $800^{\circ} \mathrm{C}$ leads to homogeneity of their crystalline structures and consequently increasing in their magnetic properties gradually with increasing ratio of La.

\subsection{FE-SEM analysis}

The typical morphologies of the products in each La ratio (0.0-0.3 \%) were observed byFE-SEM. The morphology of the $\mathrm{Zn} \mathrm{La}(\mathrm{x}) \mathrm{Fe}_{(3-\mathrm{x})} \mathrm{O}_{4}$ NPs was evaluated by FE-SEM method. Fig. 3 clearly indicates that the $\mathrm{Fe}_{3} \mathrm{O}_{4}$ spheres of ca. 30-50 nm in diameter are composed of many fine primary magnetite nanocrystals and exhibit a relatively smooth surface. These $\mathrm{Fe}_{3} \mathrm{O}_{4}$ spheres were further used as cores for the growth of La shells to obtain the $\mathrm{La}_{x} \mathrm{ZnFe304}$ NPs coreshell nanostructures.Figure 1 depicts FE-SEM micrographs and reveals that nanostructures show spherical geometry, with diameters near $20 \mathrm{~nm}$, which form irregular agglomerates with diameters from 50 to $70 \mathrm{~nm}$. This agglomerate formation indicates that the surface energy of the nanoparticles is relatively strong. Similar results are obtained by[40].Fig.3 clearly showed the uniform distribution of $\mathrm{Fe}, 0$ and $\mathrm{La}$ elements in the structure of $\mathrm{Zn} \mathrm{La}(\mathrm{x}) \mathrm{Fe}_{(3-\mathrm{x})} \mathrm{O}_{4} \mathrm{NPs}$. The iron and oxygen presence is related with iron oxide core. La was also verified in the scanning and its presence is consistent with the La nanolayer (shell). The FE-SEM results are similar that obtained by[41].Fig.1, 2 demonstrated a micrograph performed by FE-SEM and the chemical distribution obtained to $\mathrm{Zn} \mathrm{La}(\mathrm{x}) \mathrm{Fe}_{(3-\mathrm{x})} \mathrm{O}_{4} \mathrm{NPs}$ in $\mathrm{N}_{2}$ atmosphere. Fig. 4 confirms the agglomerate formation with dimensions near $100 \mathrm{~nm}$ to $300 \mathrm{~nm}$ that depict the presence of iron, oxygen and La elements, respectively.Compared to the $\mathrm{ZnFe}_{3} \mathrm{O}_{4}$ core, the outside surfaces became coarse after the growth of La layers on the surface process, as shown in Fig. 1 in $0.1,0.2$ and $0.3 \%$ La. We can say from the TEM images (Fig. 1,2 ) indicates that the La are successfully loaded onto the surfaces of $\mathrm{ZnFe}_{3} \mathrm{O}_{4}$ spheres clearly demonstrating the formation of core-shell nanostructures. The average size of $\mathrm{ZnFe}_{3} \mathrm{O}_{4}$ and $\mathrm{Zn} \mathrm{La}(\mathrm{x}) \mathrm{Fe}_{(3-\mathrm{x})} \mathrm{O}_{4} \mathrm{NPs}$ even at $\mathrm{O}_{2}$ or $\mathrm{N}_{2}$ atmosphere (Fig.3,4)are 30 and $50 \mathrm{~nm}$, respectively. Fig. 2 indicates that core-shell heterostructure is the predominant morphology of the products[42], which agrees well with the SEM observation (Fig 4). Obviously, the thickness of the outer shell with light contrast is about $10 \mathrm{~nm}$, while the diameter of the inner core with dark contrast is about $30-25 \mathrm{~nm}$. The magnified TEM image further confirms that the shell is porous and composed of nanoparticles (Fig. 2).

\subsection{Particle Size distribution}


The hydrodynamic diameter provides information about inorganic core along with functionalized/coated material and the solvent layer attached to the particle as it moves under the influence of Brownian motion.Usually, the magnetic properties of nanomaterials can be varied by increase of surface to volume ratio of particles and variation of their size.Decreasing of particles size in nanometer scales led to creation of magnetic death layer on the particles surface due to deviation of magnetic moments orientation, formation of disordering configuration of moments that are caused to develop superparamagnetic behavior (below specific critical size)[43], making a difference in normal cationic distribution in crystalline structure, and finally variation of some surface properties like ability of water absorption on surface. Furthermore, decreasing of particle size and increasing of their surfaces are very useful for biological and medical applications. In contrast, when particles size is decreased less than 10 nanometers (for many of materials), the crystallinity of particles is also decreased, so the amount of saturation magnetization is dropped off[44].

Particle size was determined by atomic force microscopy. The average size derived from the height scan was below $40 \mathrm{~nm}$. The distribution profile of sizes from the TEM height scan is shown in Fig.5a. A section of the AFM scan is included in the inset. The results from the TEM correspond to the distribution acquired from DLS (Fig.5b). The hydrodynamic diameter distribution of the $\mathrm{Zn} \mathrm{La}(\mathrm{x}) \mathrm{Fe}_{(3-x)} \mathrm{O}_{4} \mathrm{NPs}$ was of $36 \mathrm{~nm}$ and volume ratio of $16.9 \%$. The hydrodynamic diameter by DLS is slightly larger than that determined by AFM, as expected. A similar study has been performed elsewhere and it was observed that DLS was limited for accurate particle sizing and mostly DLS provides higher values. Fig. 5 indicates that the optimized co-precipitation method effectively produces a well-dispersed and narrower distribution of particle diameters[45]. The high stability of $\mathrm{Zn} \mathrm{La}(\mathrm{x}) \mathrm{Fe}_{(3-\mathrm{x})} \mathrm{O}_{4} \mathrm{NPs}$ is given by their very low electrostatic potential.

The hydrodynamic sizes of $\left(\mathrm{N}_{2}\right) \mathrm{Zn} \mathrm{La}(\mathrm{x}) \mathrm{Fe}_{(3-\mathrm{x})} \mathrm{O}_{4} \mathrm{NPs}$ and $\left(\mathrm{O}_{2}\right) \mathrm{Zn} \mathrm{La}(\mathrm{x}) \mathrm{Fe}_{(3-\mathrm{x})} \mathrm{O}_{4} \mathrm{NPs}$ were 1248 and 900 $\mathrm{nm}$, respectively. The increase in the hydrodynamic size of functionalized $\mathrm{Zn} \mathrm{La}(\mathrm{x}) \mathrm{Fe}_{(3-\mathrm{x})} \mathrm{O}_{4} \mathrm{NPs}$ is due to anincrease in La or LaOmoieties onto the surface of the magnetite $\mathrm{Zn} \mathrm{La}(\mathrm{x}) \mathrm{Fe}_{(3-x)} \mathrm{O}_{4} \mathrm{NPs}$. This demonstrates a more hydrophilic nature of $\mathrm{Zn} \mathrm{La}(\mathrm{x}) \mathrm{Fe}_{(3-\mathrm{x})} \mathrm{O}_{4} \mathrm{NPs}$ than $\mathrm{Fe}_{3} \mathrm{O}_{4} \mathrm{NPs}$. The size obtained from DLS was large as compared with TEM because in DLS dispersed NPs moves through a liquid medium and thin layer of electric dipole of the solvent adheres to its surface[46].

\subsection{X-RD and XRF analysis}

The crystalline structures of the $\mathrm{Zn} \mathrm{Fe}_{3} \mathrm{O}_{4}$ before and after doping with La were investigated by XRD (Fig. $6 a)$.

The framework peaks were weakened or vanished after $\mathrm{La}$ was added onto $\mathrm{Zn} \mathrm{Fe}_{3} \mathrm{O}_{4^{-}}$. Obvious peaks of $\mathrm{Fe}_{3} \mathrm{O}_{4}$ located at $24^{\circ}, 33,35.6^{\circ}, 54.1^{\circ}, 57.3^{\circ}$ and $62.4^{\circ}$ were detected on sample $\mathrm{ZnLa}(\mathrm{x}) \mathrm{Fe}_{(3-\mathrm{x})} \mathrm{O}_{4}$, indicating the successful loading of $\mathrm{Fe}_{3} \mathrm{O}_{4}$. No peaks corresponding to lanthanum compound was observed on the XRD pattern of $\mathrm{Zn} \mathrm{Fe}_{3} \mathrm{O}_{4}$ (Fig6a\&b). The samples of different La ratio (0.1-0.3\%) having the $\mathrm{La}$ dispersed onto structure of $\mathrm{Zn} \mathrm{La}(\mathrm{x}) \mathrm{Fe}_{(3-\mathrm{x})} \mathrm{O}_{4}$ samples. The diffraction peaks of $\mathrm{Zn} \mathrm{La}(\mathrm{x}) \mathrm{Fe}_{(3-}$ 
${ }_{x} \mathrm{O}_{4}$ samples are highly crystalline, which is consistent with the standard pattern of $\mathrm{Fe}_{2} \mathrm{O}_{4}$ (JCPDS: 01073-1964)[47]. Furthermore, the XRD patterns of $\mathrm{Zn} \mathrm{La}(\mathrm{x}) \mathrm{Fe}_{(3-\mathrm{x})} \mathrm{O}_{4}$ samples differ significantly from the $\mathrm{Zn} \mathrm{Fe} \mathrm{O}_{4}$ peaks. The major diffraction peaks at $2 \theta=22.67^{\circ}, 32.24^{\circ}, 39.74^{\circ}, 46.25^{\circ}, 57.48^{\circ}$, and $67.57^{\circ}$ could be indexed to (100), (110), (111), (200), (211), and (220) for lanthanum iron oxide [JCPDS: 01-0750541][48]. In addition, a small portion of $\mathrm{Fe}_{2} \mathrm{O}_{3}$, with peaks at $2 \theta=24.35^{\circ}, 35.71^{\circ}, 62.43^{\circ}$, and $72.68^{\circ}$, was obtained. This was thought to have originated from the transformation of unreacted iron species into $\mathrm{Fe}_{2} \mathrm{O}_{3}$ at $850{ }^{\circ} \mathrm{C}$ owing to tube furnace heating. The XRD pattern of $\mathrm{Zn} \mathrm{La}(\mathrm{x}) \mathrm{Fe}_{(3-\mathrm{x})} \mathrm{O}_{4}$ samples exhibits the corresponding diffraction peaks with lower intensity owing to the size effect and domination of the $\mathrm{Zn}$ $\mathrm{Fe}_{3} \mathrm{O}_{4}$ heterojunction.

As the La ratio was increased from 1 and $0.3 \%$, no obvious differences were observed, and the $\mathrm{Zn} \mathrm{Fe}_{3} \mathrm{O}_{4}$ were delaminated at high La ratio. Fig. 2 shows the XRD patterns of the $\mathrm{Zn} \mathrm{La}(\mathrm{x}) \mathrm{Fe}_{(3-x)} \mathrm{O}_{4}$ samples calcinations in $\mathrm{N}_{2}$ atmosphere. The $\mathrm{La}_{\mathrm{X}} \mathrm{ZnFe}_{3} \mathrm{O}_{4}$ samples calcinations in $\mathrm{N} 2$ atmosphere were not decomposed even at high ratio of La, which confirmed the stability of the material owing to the chemical interaction of the La particles with the $\mathrm{Zn} \mathrm{Fe}_{3} \mathrm{O}_{4}$. Sharp diffraction peaks of La nanoparticles were obtained (Fig. 6b), which indicated the crystalline nature of the synthesized $\mathrm{La}_{x} \mathrm{ZnFe}_{3} \mathrm{O}_{4}$ samples. Broadening of the peaks indicates that the particles formed were in the nanometer scale. Particle size were estimated from half width of the observed diffraction peaks with (101), (111), (121), (110), (111), (230), (020), (202), (022), (220), (311), (004) Brags reflection. The average particle size of the synthesized nanoparticles was $60 \mathrm{~nm}$, which was obtained using the Debeys-Scherrer equation[49].

The broad XRD diffraction peaks of $\mathrm{ZnLa}(\mathrm{x}) \mathrm{Fe}_{(3-\mathrm{x})} \mathrm{O}_{4}$ samples at $13.04^{\circ}, 22.82^{\circ}$, and $29.54^{\circ}$ are assigned to the lanthanum $\mathrm{ZnFe}_{3} \mathrm{O}_{4}$ structure (PDF No. 00-054-0212)[50]. The intensity of the $\mathrm{Zn} \mathrm{Fe}_{3} \mathrm{O}_{4}$ signals decreases as a result of the growth of crystalline $\mathrm{La}_{x} \mathrm{ZnFe}_{3} \mathrm{O}_{4}$ nanocomposites as interlayer spacers on the surface of $\mathrm{ZnFe}_{3} \mathrm{O}_{4}$ nanoparticles. This result indicates the successful deposition of $\mathrm{La}$ on the $\mathrm{ZnFe}_{3} \mathrm{O}_{4}$ nanoparticles surface.Generally the sharp diffraction peaks as well as high intensity implied the good crystallinity of $\mathrm{ZnLa}(\mathrm{x}) \mathrm{Fe}_{(3-\mathrm{x})} \mathrm{O}_{4}$ that calcinated in $\mathrm{O}_{2}$ or $\mathrm{N}_{2}$ atmosphere (Fig.6a\&b). Also, In the XRD pattern of $\mathrm{ZnLa}(\mathrm{x}) \mathrm{Fe}_{(3-x)} \mathrm{O}_{4}$ samples, the intensity of the above peaks decreased. This result might be attributed to the increases of $\mathrm{La}$ content of $\mathrm{ZnLa}(\mathrm{x}) \mathrm{Fe}_{(3-\mathrm{x})} \mathrm{O}_{4}$ samples which were dispersed onto the surface of $\mathrm{ZnFe}_{3} \mathrm{O}_{4}$ nanoparticles .

The chemical composition of the nanoparticles sample was examined by XRF analysis. The peak clearly indicated the presence of three essential constituents $\mathrm{Zn}, \mathrm{La}, \mathrm{O}$ and Fe with La occupying different percentage (Table.1). The different $\mathrm{La}(0.1-0.25 \%)$ elemental ratios was here excellent agreement with the molecular composition of $\mathrm{ZnLa}(\mathrm{x}) \mathrm{Fe}_{(3-\mathrm{x})} \mathrm{O}_{4}$ nanoparticles samples. This clearly indicates that $\mathrm{ZnLa}(\mathrm{x}) \mathrm{Fe}_{(3-x)} \mathrm{O}_{4}$ nanoparticles have been successfully synthesized. The increase in La element percentage alongside peaks of iron and oxygen are shown in Table.1. The $\%$ of oxygen is relatively high due to the contribution of oxygen from $\mathrm{LaO}$ used in coating the surface of $\mathrm{ZnFe}_{3} \mathrm{O}_{4}$ nanoparticles. Further 
functionalization with La element is shown in Table.1. The \% of oxygen is dramatically increased due to contribution of oxygen from $\mathrm{LaO}[50]$.

Table. 1 XRF analyses of $\mathrm{ZnLa}(\mathrm{x}) \mathrm{Fe}_{(3-\mathrm{x})} \mathrm{O}_{4}$ nanoparticles.

\begin{tabular}{|c|c|c|c|c|}
\hline \multicolumn{5}{|l|}{ XRF analysis } \\
\hline \multirow{2}{*}{$\begin{array}{l}\text { Samples } \\
\text { Key }\end{array}$} & \multicolumn{4}{|c|}{ molecular formula } \\
\hline & $\mathrm{Fe}$ & $\mathrm{Zn}$ & La & 0 \\
\hline $0 \% \mathrm{La}$ in $\mathrm{O}_{2}$ atmosphere & 1.67 & 1 & 0 & 3.67 \\
\hline $0 \%$ La in $\mathrm{N}_{2}$ atmosphere & 1.18 & 1 & 0 & 3.18 \\
\hline $0.1 \% \mathrm{La}$ in $\mathrm{O}_{2}$ atmosphere & 0.98 & 1 & 0.085 & 2.98 \\
\hline $0.1 \% \mathrm{La}$ in $\mathrm{N}_{2}$ atmosphere & 1.48 & 1 & 0.108 & 3.48 \\
\hline $0.2 \%$ La in $\mathrm{O}_{2}$ atmosphere & 1.4 & 1 & 1.7 & 3.5 \\
\hline $0.2 \%$ La in $\mathrm{N}_{2}$ atmosphere & 1.07 & 1 & 0.09 & 3.07 \\
\hline $0.3 \% \mathrm{La}$ in $\mathrm{O}_{2}$ atmosphere & 1.02 & 1 & 0.23 & 3.02 \\
\hline $0.3 \%$ La in $\mathrm{N}_{2}$ atmosphere & 1.9 & 1 & 0.26 & 4 \\
\hline
\end{tabular}

\subsection{Thermal Analyses (TGA and DSC)}

Thermogravimetric analysis (TGA) was employed to study the thermal stability of $\mathrm{ZnLa}(\mathrm{x}) \mathrm{Fe}_{(3-}$ x) $\mathrm{O}_{4}$ magnetic NPs that calcinated in $\mathrm{O}_{2}$ and $\mathrm{N}_{2}$ atmosphere (Fig. 7a\&b). As shown in the TG plot, the magnetic composite supported a $40.09 \%$ weight loss at approximately $200-344{ }^{\circ} \mathrm{C}$ and $242-353^{\circ} \mathrm{C}$ for $0.3 \mathrm{La}$ calcinated in $\mathrm{N}_{2}$ and $\mathrm{O}_{2}$ atmosphere, respectively, which was ascribed to the which demonstrated the content of the $\mathrm{LaO}$ coating. For the magnetic composite, the second degradation step ranges between $443-672{ }^{\circ} \mathrm{C}$ and $434-672{ }^{\circ} \mathrm{C}$ for $0.3 \mathrm{La}$ calcinated in $\mathrm{N}_{2}$ and $\mathrm{O}_{2}$ atmosphere with weight loss of $1.1 \%$ and $2.76 \%$, respectively. The degradation step indicate the decomposition of magnetite core of the $\mathrm{ZnLa}(\mathrm{x}) \mathrm{Fe}_{(3-\mathrm{x})} \mathrm{O}_{4}$ magnetic NPs[50].Differential scanningcalorimetric analysis (DSC) curve of $\mathrm{ZnLa}(\mathrm{x}) \mathrm{Fe}_{(3-}$ ${ }_{x)} \mathrm{O}_{4}$ shows two endothermic main peaks at 168,165 and $684,648{ }^{\circ} \mathrm{C}[51]$ for $0.3 \mathrm{La}$ calcinated in $\mathrm{N}_{2}$ and $\mathrm{O}_{2}$ atmosphere, which suggest the removal of La shell and decomposition of $\mathrm{ZnLa}(\mathrm{x}) \mathrm{Fe}_{(3-\mathrm{x})} \mathrm{O}_{4} \mathrm{NPs}$ respectively.

\subsection{Zeta optional of nanoparticles}

Zeta-potential measurements were further used to confirm the presence of La on the surface of $\mathrm{ZnFe}_{3} \mathrm{O}_{4}$ NPs. As shown in Fig. 8a\&b, the zeta potential of $\left(\mathrm{N}_{2}\right) \mathrm{ZnFe}_{3} \mathrm{O}_{4} \mathrm{NPs}$ is increased with increasing La 
percentagedue to presence of La metal not La oxide on the surface, while the zeta potential of $\left(\mathrm{O}_{2}\right)$ $\mathrm{ZnFe}_{3} \mathrm{O}_{4} \mathrm{NPs}$ is decreases derived from the -ve charge of surface LaO as shown in Fig.8a. The $\left(\mathrm{O}_{2}\right)$ $\mathrm{La}_{0.3} \mathrm{ZnFe}_{3} \mathrm{O}_{4} \mathrm{NPs}$ shows a higher zeta potential of $-13.2 \mathrm{mV}$ derived from the -ve charge of LaO. Calcinations of $\mathrm{Zn} \mathrm{La}(\mathrm{x}) \mathrm{Fe}_{(3-\mathrm{x})} \mathrm{O}_{4} \mathrm{NPs}$ in $\mathrm{N}_{2}$ atmosphere (Fig.8b) , lead to a increases of zeta potential, which is due to the fact that the La have +ve not LaO (-ve) charge crystal[50,51]. So the biomedical activity of $\mathrm{ZnFe}_{3} \mathrm{O}_{4} \mathrm{NPs}$ calcinated in $\mathrm{N}_{2}$ atmosphere is more effective in killing bacteria with respect to $\mathrm{O}_{2}$ calcinated samples.

\subsection{Photoluminescence spectroscopy analysis}

The separation of between electron and hole is one of the important parameters influencing photocatalytic performance. In this context, photoluminescence spectroscopy was employed in order to evaluate the recombination rate for the photo generated electron-hole pairs for the $\mathrm{ZnLa}(x) \mathrm{Fe}(3-x) \mathrm{O}_{4}$ at $\mathrm{N}_{2}$ and $\mathrm{O}_{2}$ calcinations conditions (see Fig. 9).

The concentration of $\mathrm{La}$ ion in $\mathrm{ZnLa}(\mathrm{x}) \mathrm{Fe}(3-\mathrm{x}) \mathrm{O}_{4}$ synthesis is one of the most important factor that can affect the optical properties of $\mathrm{ZnLa}(x) \mathrm{Fe}_{(3-x)} \mathrm{O}_{4}$. It is well illustrated that the excitation is generated by the photon absorption, which leads to band-edge and $\mathrm{Zn}^{2+}$ ion-related luminescence processes. The effect of concentration of $\mathrm{La}^{3+}$ ion as dopant was studied from $0.1 \%$ to $0.3 \%$ in the synthesis of $\mathrm{ZnLa}(x) \mathrm{Fe}_{(3-x)} \mathrm{O}_{4}$. Fig. 9 shows the PL spectra of the $\mathrm{ZnLa}(x) \mathrm{Fe}_{(3-x)} \mathrm{O}_{4}$ at $\mathrm{N}_{2}$ and $\mathrm{O}_{2}$ calcinations conditions.

The lowest intensity for PL spectrum of the $\mathrm{ZnLa}(x) \mathrm{Fe}_{(3-x)} \mathrm{O}_{4}$ calcinated in $\mathrm{O}_{2}(\mathrm{Fig} \mathrm{9a})$ atmosphere reveals that recombination rate of the charges in this nanocomposite is the lowest in comparison with the $\mathrm{Zn}$ $\mathrm{La}(x) \mathrm{Fe}_{(3-x)} \mathrm{O}_{4}$ calcinated in $\mathrm{N}_{2}$ atmosphere (Fig 9b). For both composites enhancement in intensity was observed with increasing La concentration (Fig. 9) and this enhancement was larger for $\mathbf{C} \mathbf{1}$ confirming more effective interaction with $\mathrm{Fe}_{(3-x)} \mathrm{O}_{4}$. In fact, low intensity in $\mathrm{PL}$ spectrum of $\mathrm{ZnLa}(x) \mathrm{Fe}_{(3-x)} \mathrm{O}_{4}$ calcinated in $\mathrm{O}_{2}$ atmosphere indicates that separation between the charge carriers is enhanced, leading to contribution of more electrons and holes in the oxidation and reduction reactions. The PL spectra appeared in the region between 700 and $800 \mathrm{~nm}$, being identical for all the samples. In this way, the peaks around $733 \mathrm{~nm}$ arise from defect state luminescence. Besides, the bands at around $423 \mathrm{~nm}$ can also be related to recombination of free excitations. Therefore, the electron-hole separation efficiency can be improved, resulting in the increase in photo catalytic activity. The spectrum of $\mathrm{ZnLa}(x) \mathrm{Fe}_{(3-x)} \mathrm{O}_{4}$ calcinated in $\mathrm{O}_{2}$ and $\mathrm{N}_{2}$ atmosphere have the peak at $423 \mathrm{~nm}$ which is originated from defects caused by missing of some $\mathrm{Zn}$ ion in $\mathrm{ZnLa}(x) \mathrm{Fe}_{(3-x)} \mathrm{O}_{4}$ due to replacement of $\mathrm{Zn}$ with La in the crystal structure, and the peak at $733 \mathrm{~nm}$ which is originated from the $4 \mathrm{~T} 1 \rightarrow 6 \mathrm{~A} 1$ transition in $3 \mathrm{~d} 5$ electronic layer of $\mathrm{Zn}$ (II) ion. However the intensity of the peak at $423 \mathrm{~nm}$ of $\mathrm{ZnLa}(x) \mathrm{Fe}_{(3-x)} \mathrm{O}_{4}$ calcinated in $\mathrm{O}_{2}$ atmosphere is lower than that calcinated in $\mathrm{N}_{2}$ atmosphere. These results indicate that $\mathrm{ZnLa}(x) \mathrm{Fe}_{(3-x)} \mathrm{O}_{4}$ nanoparticles contain La ions and have similar PL properties with $\mathrm{Zn} \mathrm{Fe}_{(3-\mathrm{x})} \mathrm{O}_{4}$ nanoparticles in visible region, which can be used for labeling application in biomedicine. 


\subsection{Biological Activity}

Fig. 10 show the results of descriptive indices for values of inhibition zone diameter and growth numbers of bacterial colonies at differentweight percentas $\mathrm{G} 1$ to G13of calcined $\mathrm{ZnLa}(\mathrm{x}) \mathrm{Fe}_{(3-\mathrm{x})} \mathrm{O}_{4} \mathrm{NPsagainst}$ different kind of bacteria.Where samples $\mathrm{G} 1$ to $\mathrm{G} 13$ are given in Table 2.

Table 2. Samples Key of different weight percent as $\mathrm{G} 1$ to $\mathrm{G} 13$ of calcined $\mathrm{ZnLa}(\mathrm{x}) \mathrm{Fe}_{(3-\mathrm{x})} \mathrm{O}_{4} \mathrm{NPs}$ against different kind of bacteria.

\begin{tabular}{|c|c|}
\hline Key & $\mathrm{La}$ and $\mathrm{Zn}$ in calcined $\mathrm{ZnLa}(\mathrm{x}) \mathrm{Fe}_{(3-\mathrm{x})} \mathrm{O}_{4} \mathrm{NPs}$ \\
\hline G1 & La $0.0 \%$ in $\mathrm{O}_{2}$ atmosphere, in calcined $\mathrm{ZnFe}_{3} \mathrm{O}_{4} \mathrm{NPs}$ \\
\hline G3 & La $0.0 \%$ in $\mathrm{N}_{2}$ atmosphere, in calcined $\mathrm{ZnFe}_{3} \mathrm{O}_{4} \mathrm{NPs}$ \\
\hline G4 & La $0.1 \%$ in $\mathrm{O}_{2}$ atmosphere in calcined $\mathrm{ZnLa}(\mathrm{x}) \mathrm{Fe}_{(3-\mathrm{x})} \mathrm{O}_{4} \mathrm{NPs}$ \\
\hline G5 & La $0.3 \%$ in $\mathrm{O}_{2}$ atmosphere in calcined $\mathrm{ZnLa}(\mathrm{x}) \mathrm{Fe}_{(3-\mathrm{x})} \mathrm{O}_{4} \mathrm{NPs}$ \\
\hline G6 & La $0.10 \%$ in $\mathrm{N}_{2}$ atmosphere in calcined $\mathrm{ZnLa}(\mathrm{x}) \mathrm{Fe}_{(3-\mathrm{x})} \mathrm{O}_{4} \mathrm{NPs}$ \\
\hline G7 & La $0.30 \%$ in $\mathrm{N}_{2}$ atmosphere in calcined $\mathrm{ZnLa}(\mathrm{x}) \mathrm{Fe}_{(3-\mathrm{x})} \mathrm{O}_{4} \mathrm{NPs}$ \\
\hline G8 & La $0.15 \%$ in $\mathrm{O}_{2}$ atmosphere in calcined $\mathrm{ZnLa}(\mathrm{x}) \mathrm{Fe}_{(3-\mathrm{x})} \mathrm{O}_{4} \mathrm{NPs}$ \\
\hline G9 & La $0.15 \%$ in $\mathrm{N}_{2}$ atmosphere in calcined $\mathrm{ZnLa}(\mathrm{x}) \mathrm{Fe}_{(3-x)} \mathrm{O}_{4} \mathrm{NPs}$ \\
\hline G10 & La $0.20 \%$ in $\mathrm{O}_{2}$ atmosphere in calcined $\mathrm{ZnLa}(\mathrm{x}) \mathrm{Fe}_{(3-x)} \mathrm{O}_{4} \mathrm{NPs}$ \\
\hline G11 & La $0.20 \%$ in $\mathrm{N}_{2}$ atmosphere in calcined $\mathrm{ZnLa}(\mathrm{x}) \mathrm{Fe}_{(3-x)} \mathrm{O}_{4} \mathrm{NPs}$ \\
\hline G12 & La $0.25 \%$ in $\mathrm{O}_{2}$ atmosphere in calcined $\mathrm{ZnLa}(\mathrm{x}) \mathrm{Fe}_{(3-\mathrm{x})} \mathrm{O}_{4} \mathrm{NPs}$ \\
\hline G13 & La $0.25 \%$ in $\mathrm{N}_{2}$ atmosphere in calcined $\mathrm{ZnLa}(\mathrm{x}) \mathrm{Fe}_{(3-\mathrm{x})} \mathrm{O}_{4} \mathrm{NPs}$ \\
\hline
\end{tabular}

BasedontheresultspresentedinFig.10, thehighest inhibition zone diameter was $25 \mathrm{mg} / \mathrm{mL}$ at $0.2 \% \mathrm{La}$ doped magnetite $\mathrm{O}_{2}$; while thelower inhibition zone diameter of $E$. colik88 was $15 \mathrm{mg} / \mathrm{mL}$. which obtained at the two nanoparticles concentration of from $0.1 \%$ to $0.3 \%$ La-doped magnetite $\left(\mathrm{N}_{2}\right)$. Diameter zone inhibition of $E$. coli bacteria was $17,18,19,20,22$ and $23 \mathrm{mg} / \mathrm{mL}$ comparison to $100 \%$ of control at nanoparticle concentrations nanoparticle samples of $\mathrm{La} 0.1 \%$ in $\mathrm{O}_{2}, \mathrm{La} 0.2 \%$ in $\mathrm{N}_{2}$, $\mathrm{La} 0.3 \%$ in $\mathrm{O}_{2}$, and $\mathrm{La}$ $0.1 \%$ in $\mathrm{O}_{2}$ respectively Fig. 10.Results for E. colin Fig. 10 was observedthat number of $E$. coli K88 growth coloniesvaluesindifferentconcentrations of $\mathrm{ZnLa}(\mathrm{x}) \mathrm{Fe}_{(3-\mathrm{x})} \mathrm{O}_{4} \mathrm{NPswas}$ significant different $(p<0.05)$ at nanoparticles of $\mathrm{G}_{10}, \mathrm{G}_{5}, \mathrm{G}_{4}, \mathrm{G}_{1}, \mathrm{G}_{12}, \mathrm{G}_{8}, \mathrm{G}_{6} \& \mathrm{G}_{3}$ and $\mathrm{G}_{9}$. And had non-significant different $(p<0.05)$ of bacterial growth no. colonies at nanoparticles of $\mathrm{G}_{11}$ and $\mathrm{G}_{13}$. The bacterial growth no. colonies in 
ascending order was $37,38,41,43,46,55,65,66,68,71$ and $73 \%$ at nanoparticlesconcentrations of $\mathrm{G}_{10}$, $\mathrm{G}_{5}, \mathrm{G}_{4}, \mathrm{G}_{1}, \mathrm{G}_{12}, \mathrm{G}_{8}, \mathrm{G}_{7}, \mathrm{G}_{6 \&} \mathrm{G}_{3}, \mathrm{G}_{9}, \mathrm{G}_{11}$ and $\mathrm{G}_{13} \mathrm{mg} / \mathrm{mL}$.

Data in Fig. 11 showed that Laincreasing inhibitory effects and decreasing bacterial growth numbers of different kinds of positive and negative bacteriaas the concentrations increasedLainZnLa(x) $\mathrm{Fe}_{(3-}$ ${ }_{x)} \mathrm{O}_{4} \mathrm{NPsmay}$ distort and damage bacterial cell membrane, resulting effect onbacterial cellular contents and death of bacterial cells.

\section{Conclusion}

The present research involved preparation of magnetite nanoparticles doped with $\mathrm{Zn}$ and $\mathrm{La}$ of the general formula $\mathrm{ZnLa}(\mathrm{x}) \mathrm{Fe}_{(3-\mathrm{x})} \mathrm{O}_{4}$ where $\mathrm{x}=0.0,0.1,0.15,0.2,0.25$ and 0.3 ; which were prepared via coprecipitation method, separated and calcined at $800^{\circ} \mathrm{C}$ under oxygen and nitrogen atmospheres. The stoichiometric ratios of the elements in the given general formula had been proved and confirmed by elemental analyses using XRF. Various techniques have been used to analyze the prepared nanoparticles. X-ray diffraction (XRD) confirmed the formation of one single phase of nanoparticles components with average crystalline size. The morphology of the prepared magnetite nanoparticles was studied using field emission scanning electron microscope (FE-SEM) and high-resolution transmission electron microscope (HRTEM). Magnetic properties of the given samples obtained from vibrating sample magnetometer (VSM); showed that most of these samples exhibited almost superparamagnetic behavior. The evaluated magnetic and optical properties of the novel prepared $\mathrm{Zn} \mathrm{La}(x) \mathrm{Fe}_{(3-x)} \mathrm{O}_{4}$ nano-materials revealed their possible use in different industrial fields like bio-applications, in electronic components, cosmetics, antibacterial agents, and in solar cells. The antibacterial activity study of the prepared NPs revealed them highly efficient against different kinds of bacteria that increase with increase of La \% doped in their entity.

\section{Declarations}

\section{Credit author statement}

1- Mohamed A. Zayed. - Suggested the idea, supervised the work, revised the manuscript and provided essential advice. Close supervision of all experimental work, characterizations and analyses, made amendments and corrections of the first draft and submit the manuscript for publication.

2 - Mahmoud Fathy Mubarak Performed most of experimental work, characterizations and analyses of this work and wrote the first draft of the manuscript.

3- Gehad M. Abdel-maksoud. - Performed some of the experimental work, and preparation of magnetite nanoparticles.

\section{Declaration of Competing Interest}


The authors declare that they have no known competing financial interests or personal relationships that could have appeared to influence the work reported in this paper.

\section{Acknowledgement}

Authors acknowledge the support of this research by instruments, chemicals and measurements, given by the Chemistry Departments, Faculty of Science Cairo University, and Egyptian Petroleum Research Institute (EPRI),Ahmed El-Zomer, Nasr City, Egypt.

\section{References}

1. Amato I, Carroll L (1999) Nanotechnology: shaping the world atom by atom. National Science and Technology Council, Committee on Technology, Interagency Working Group on Nanoscience, Engineering, and Technology

2. Bhushan B (2015) Governance, policy, and legislation of nanotechnology: a perspective. Microsyst Technol 21(5):1137-1155

3. Rahmandoust M, Ayatollahi MR (2019) Nanomaterials for Advanced Biological Applications, vol 104. Springer

4. Laurent $S$ et al (2008) Magnetic iron oxide nanoparticles: synthesis, stabilization, vectorization, physicochemical characterizations, and biological applications. Chemical reviews 108(6):20642110

5. Barnaby SN, Lee A, Mirkin CA, Probing the inherent stability of siRNA immobilized on nanoparticle constructs. Proceedings of the National Academy of Sciences (2014) 111(27): p. 9739-9744

6. Wu W et al (2015) Recent progress on magnetic iron oxide nanoparticles: synthesis, surface functional strategies and biomedical applications. Sci Technol Adv Mater 16(2):023501

7. Laurent $S$ et al (2011) Magnetic fluid hyperthermia: focus on superparamagnetic iron oxide nanoparticles. Advances in colloid interface science 166(1-2):8-23

8. Tang $\mathrm{J}$ et al (2003) Magnetite Fe304 nanocrystals: spectroscopic observation of aqueous oxidation kinetics. J Phys Chem B 107(30):7501-7506

9. Rao KS et al (2018) Controlled phase evolution and the occurrence of single domain CoFe2O4 nanoparticles synthesized by PVA assisted sol-gel method. J Magn Magn Mater 451:602-608

10. Ibrahim E et al (2018) Electric, thermoelectric and magnetic characterization of $\mathrm{Y}$-Fe2O3 and $\mathrm{Co3O} 4$ nanoparticles synthesized by facile thermal decomposition of metal-Schiff base complexes. Mater Res Bull 99:103-108

11. de Mello LB et al (2019) Co-precipitation synthesis of (Zn-Mn)-co-doped magnetite nanoparticles and their application in magnetic hyperthermia. J Alloy Compd 779:698-705

12. Spaldin NA (2010) Magnetic materials: fundamentals and applications. Cambridge University Press

13. $\mathrm{Ma} \mathrm{X}$ et al (2010) Interactions between engineered nanoparticles (ENPs) and plants: phytotoxicity, uptake and accumulation. Science of the total environment 408(16):3053-3061 
14. Nel A et al (2006) Toxic potential of materials at the nanolevel. science 311(5761):622-627

15. Barkalina $\mathrm{N}$ et al., Nanotechnology in reproductive medicine: emerging applications of nanomaterials. Nanomedicine: Nanotechnology, Biology and Medicine, 2014. 10(5): p. e921-e938

16. Hofmann-Amtenbrink M, Grainger DW, Hofmann $\mathrm{H}$, Nanoparticles in medicine: Current challenges facing inorganic nanoparticle toxicity assessments and standardizations. Nanomedicine: Nanotechnology, Biology and Medicine (2015) 11(7): p. 1689-1694

17. Zayed MA et al (2016) Analytical Characterization of Hematite / Magnetite Ferrofluid Nanocomposites for Hyperthermia Purposes. J Supercond Novel Magn 29(11):2899-2916

18. Zayed MA et al (2017) Spectrophotometric analysis of hematite/magnetite nanocomposites in comparison with EDX and XRF techniques. J Mol Liq 231:288-295

19. Zélis PM et al., Structural and magnetic study of zinc-doped magnetite nanoparticles and ferrofluids for hyperthermia applications. Journal of Physics D: Applied Physics, 2013. 46(12)

20. Amir M et al (2015) Electrical properties and hyperfine interactions of boron doped Fe304 nanoparticles. Superlattices Microstruct 88:450-466

21. Hu L et al (2012) Effect of Cobalt Doping Concentration on the Crystalline Structure and Magnetic Properties of Monodisperse CoxFe3-xO4 Nanoparticles within Nonpolar and Aqueous Solvents. J Phys Chem C 116(7):4349-4355

22. Byrne JM et al (2014) Biosynthesis of Zinc Substituted Magnetite Nanoparticles with Enhanced Magnetic Properties. Adv Func Mater 24(17):2518-2529

23. Zhu S et al (2016) Evaluation of zinc-doped magnetite nanoparticle toxicity in the liver and kidney of mice after sub-chronic intragastric administration. Toxicology Research 5(1):97-106

24. Fantechi $E$ et al (2015) Influence of cobalt doping on the hyperthermic efficiency of magnetite nanoparticles. J Magn Magn Mater 380:365-371

25. Zhang Y, Kohler N, Zhang M (2002) Surface modification of superparamagnetic magnetite nanoparticles and their intracellular uptake. Biomaterials 23(7):1553-1561

26. Pankhurst QA et al., Progress in applications of magnetic nanoparticles in biomedicine. Journal of Physics D: Applied Physics, 2009. 42(22)

27. Allard GRJ, Synthesis and Characterization of Zinc-Doped Magnetic. MSc in nanoscience,Faculty of Natural ScienceUniversity of the Western Cape,Cape Town, South Africa, 2015

28. Bloemen $\mathrm{M}$ et al (2014) Synthesis and Characterization of Holmium-Doped Iron Oxide Nanoparticles. Materials (Basel) 7(2):1155-1164

29. M. T. FARID*, I.A., S. AMAN, M. KANWAL, G. MURTAZA, and I.A. I. ALI, M. ISHFAQ, <STRUCTURAL, ELECTRICAL AND DIELECTRIC BEHAVIOR OFNixCo1-xNdyFe2-yO4 NANO-FERRITES SYNTHESIZEDBY SOL-GEL METHOD>. Digest Journal of Nanomaterials and Biostructures, 2015. 10: p. 265-275.

30. Pervaiz E, Gul IH, Influence of Rare Earth (Gd3+) on Structural, Gigahertz Dielectric and Magnetic Studies of Cobalt ferrite. Journal of Physics: Conference Series (2013) 439 
31. J. MA, Y.J., M. TIAN, <Preparation and characterizationof La- and Ni-doped magnetite nanoparticles>. Materials Science-Poland, 2009. 27.

32. Shlapa $\mathrm{Y}$ et al (2016) Iron-Doped (La,Sr)MnO3 Manganites as Promising Mediators of SelfControlled Magnetic Nanohyperthermia. Nanoscale Res Lett 11(1):24

33. Balusamy B et al (2012) Characterization and bacterial toxicity of lanthanum oxide bulk and nanoparticles. J Rare Earths 30(12):1298-1302

34. Fathy $\mathrm{M}$ et al (2017) Study the adsorption of sulfates by high cross-linked polystyrene divinylbenzene anion-exchange resin. Applied Water Science 7(1):309-313

35. BrabuBalusamy Y, Kandhasamy,AnithaSenthamizhan,Gopalakrishnan,Chandrasekaran, Siva M, Subramanian, Tirukalikundram SKumaravel, Characterization and bacterial toxicity of lanthanum oxide bulk and nanoparticles. Journal of Rare Earths (2012) 30(12): p. 1298-1302

36. Sakiyan I, Arslan EL,S, Sari N., Antimicrobial activities of N-(2-hydroxy-1-naphthalidene)-amino acid (glycine, alanine, phenylalanine, histidine, tryptophane) Schiff bases and their manganese (III) Biom 2004. 17: p. 115-120

37. Mahdavi M, Haron MBA,MJ, Namvar F, Nadi B, Rahman MZ, Amin J (2013) Synthesis, surface modification and characterization of biocompatible magnetic iron oxide nanoparticles for biomedical applications. Molecules 18:7533-7548

38. Qureshi AA et al (2021) Facile formation of SnO2-TiO2 based photoanode and Fe304@rGO based counter electrode for efficient dye-sensitized solar cells. Mater Sci Semicond Process 123:105545

39. Shi M et al., Preparation and properties of GO-based lanthanum ion-imprinted polymer, La-IIPMAA/Fe304-GO. Journal of Rare Earths, 2020

40. Ahmed S, Lo IMC (2020) Phosphate removal from river water using a highly efficient magnetically recyclable Fe304/La(OH)3 nanocomposite. Chemosphere 261:128118

41. Altaf R et al (2021) Modified magnetite adsorbent (Zr-La@Fe304) for nitrilotrismethylenephosphonate (NTMP) removal and recovery from wastewater. J Clean Prod 278:123960

42. Sundaresan $P$ et al (2019) Simple sonochemical synthesis of lanthanum tungstate (La2(WO4)3) nanoparticles as an enhanced electrocatalyst for the selective electrochemical determination of antiscald-inhibitor diphenylamine. Ultrason Sonochem 58:104647

43. Li C et al (2021) Adsorption and mechanism study for phosphonate antiscalant HEDP removal from reverse osmosis concentrates by magnetic La/Zn/Fe304@PAC composite. Colloids Surf A 613:126056

44. Wu Z et al (2020) Core-shell magnetic Fe304@Zn/Co-ZIFs to activate peroxymonosulfate for highly efficient degradation of carbamazepine. Appl Catal B 277:119136

45. Zhang H-M et al (2019) Fe304 encapsulated in porous carbon nanobowls as efficient oxygen reduction reaction catalyst for Zn-air batteries. Chem Eng J 375:122058 
46. Saha P, Rakshit R, Mandal K (2019) Enhanced magnetic properties of Zn doped Fe304 nano hollow spheres for better bio-medical applications. J Magn Magn Mater 475:130-136

47. Gonzalez-Guerrero M, Gomez FA (2019) An all-printed 3D-Zn/Fe304 paper battery. Sens Actuators B 289:226-233

48. Meng $Z$ et al (2019) Removing anionic dyes from wastewater based on in-situ formation of Fe304@Zn-Al layered double hydroxides by self-assembly. Appl Clay Sci 170:41-45

49. Pal M et al (2017) Direct immobilization of antibodies on Zn-doped Fe304 nanoclusters for detection of pathogenic bacteria. Anal Chim Acta 952:81-87

50. Manjunatha CR et al (2019) Perovskite lanthanum aluminate nanoparticles applications in antimicrobial activity, adsorptive removal of Direct Blue 53 dye and fluoride. Materials Science Engineering: C 101:674-685

51. Kumari A et al (2020) Constructing Z-scheme LaTiO2N/g-C3N4@Fe3O4 magnetic nano heterojunctions with promoted charge separation for visible and solar removal of indomethacin. Journal of Water Process Engineering 36:101391

\section{Figures}

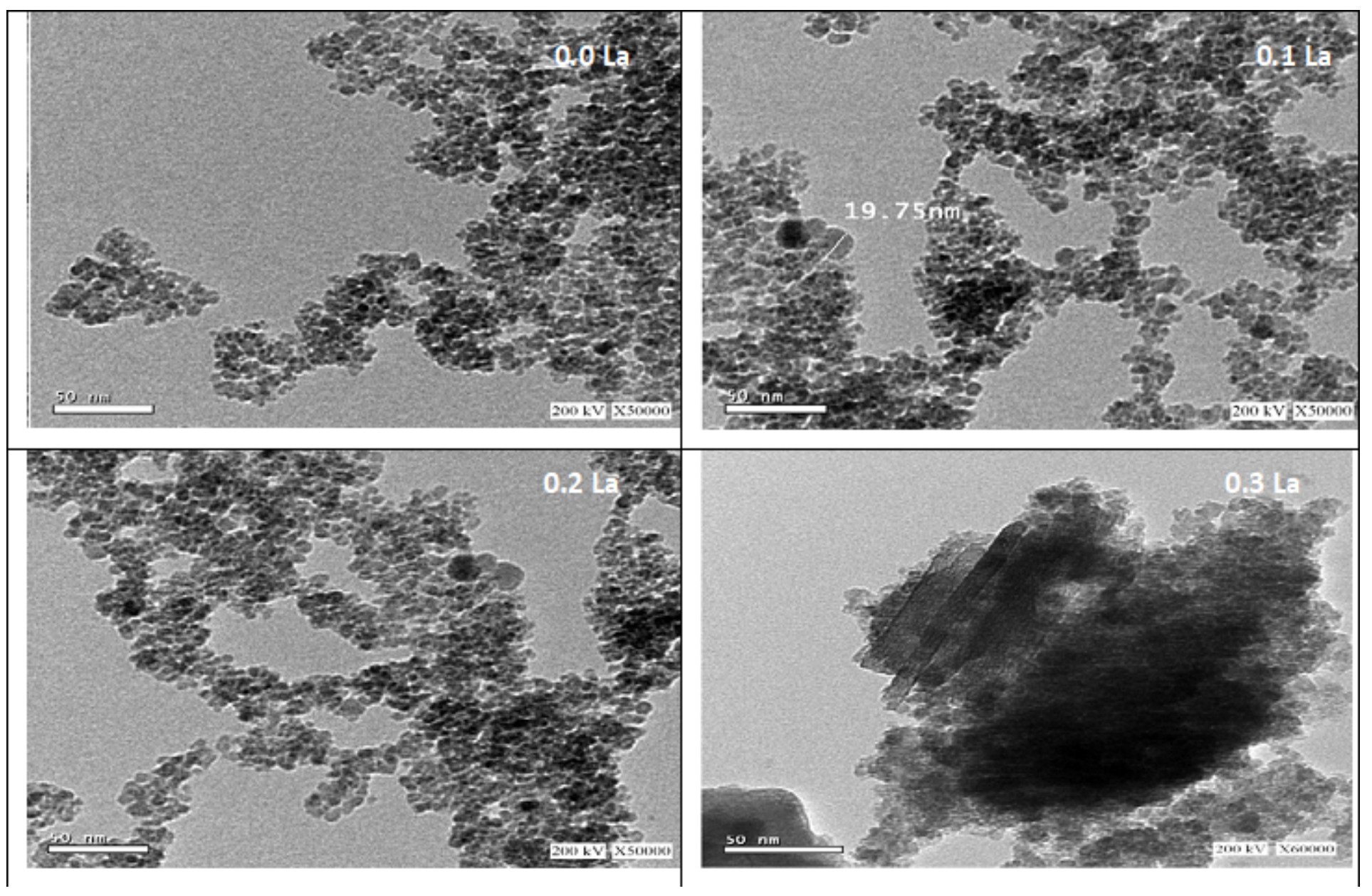

Figure 1 
HRTEM of Fe304nano-powders co-doped with Zn2+ ions and different La3+ ion molar ratio synthesized via co-precipitation route under $\mathrm{N} 2$ atmosphere and annealing at $800 \mathrm{oC}$ for $2 \mathrm{~h}$

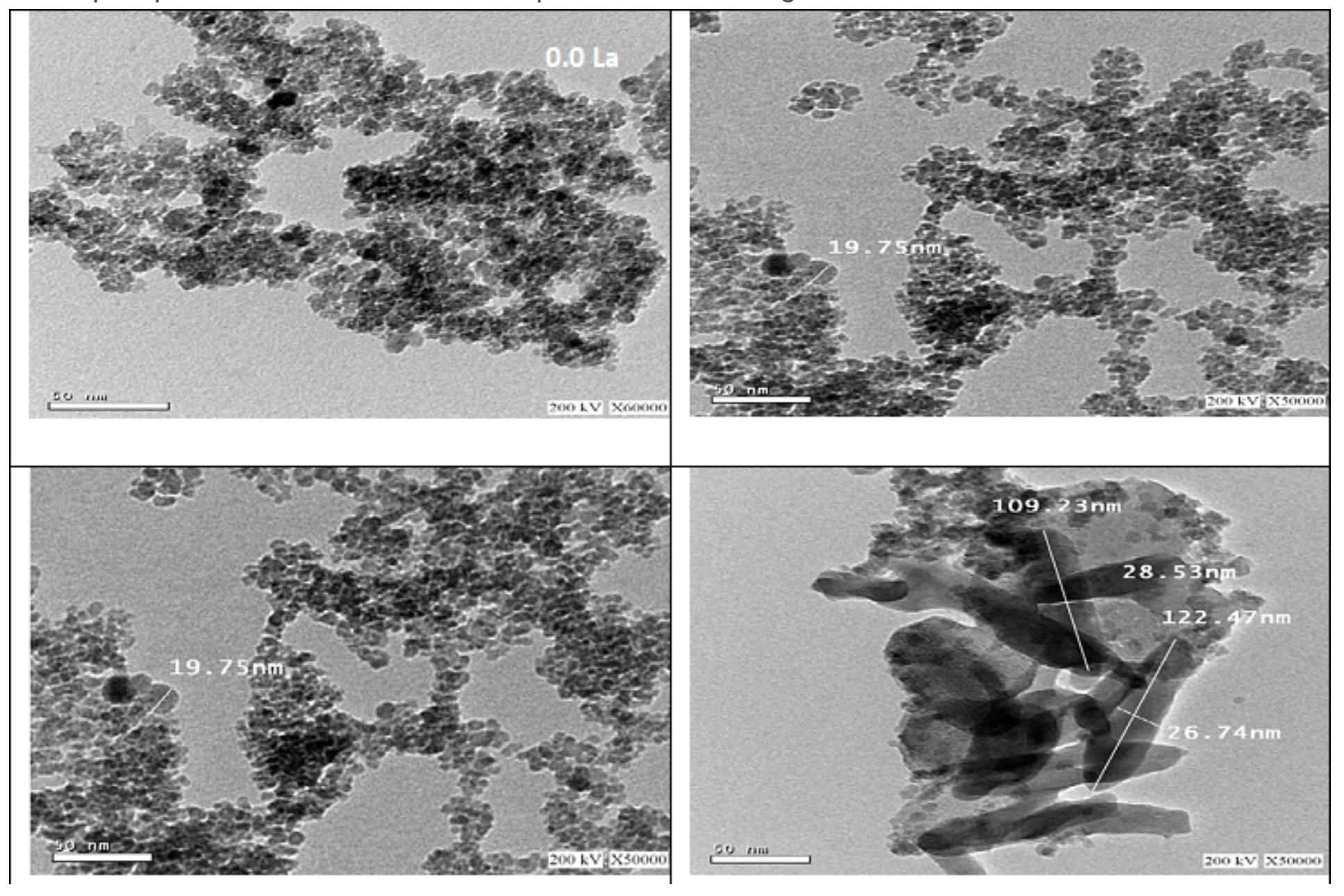

Figure 2

HRTEM of Fe304nano-powders co-doped with Zn2+ ions and different La3+ ion molar ratio synthesized via co-precipitation route under 02 atmosphere and annealing at $800 \mathrm{oC}$ for $2 \mathrm{~h}$ 

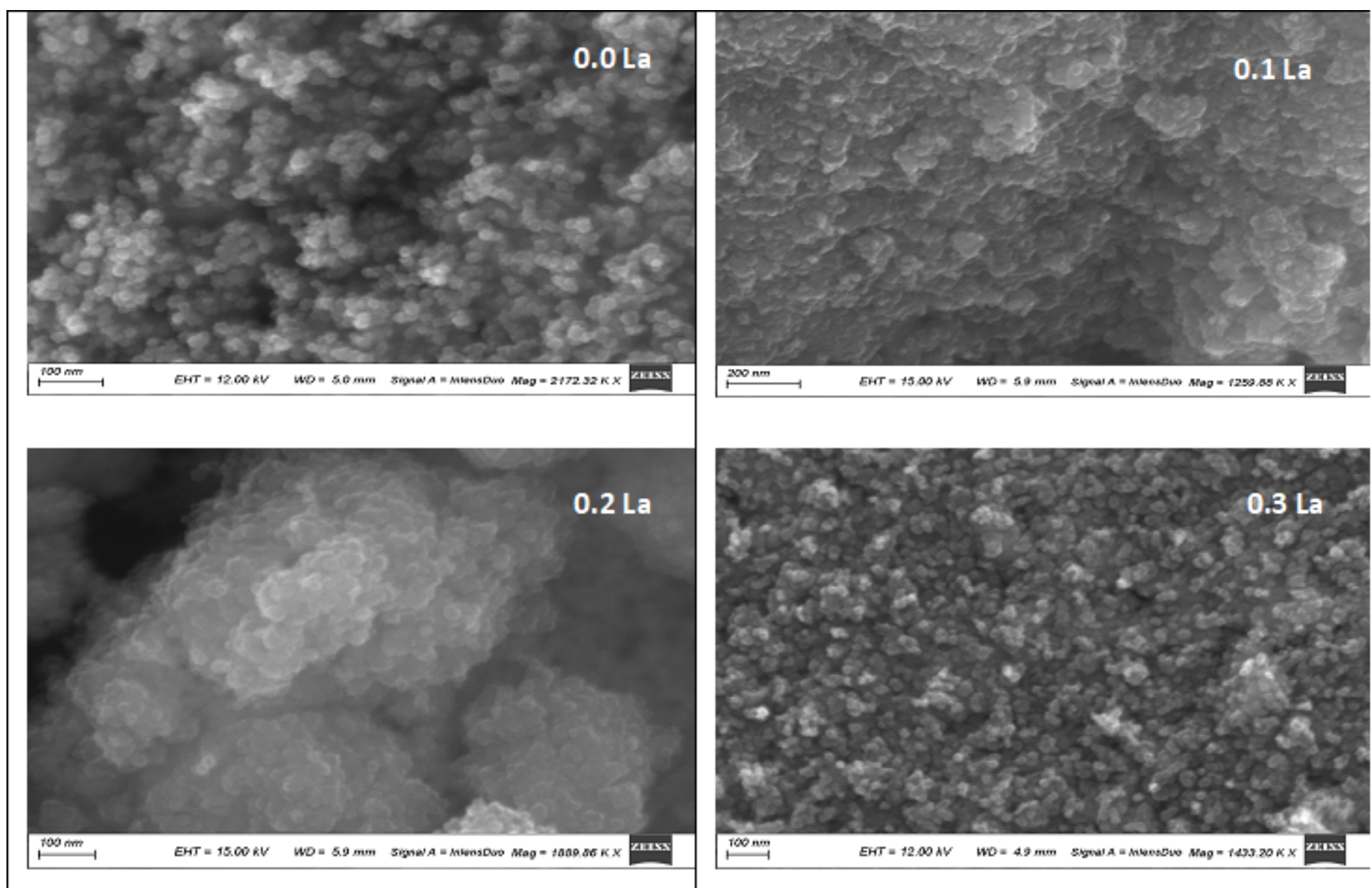

\section{Figure 3}

FESEM of Fe304nano-powders co-doped with Zn2+ ions and different La3+ ion molar ratio synthesized via co-precipitation route under $\mathrm{O} 2$ atmosphere and annealing at $800 \mathrm{oC}$ for $2 \mathrm{~h}$ 


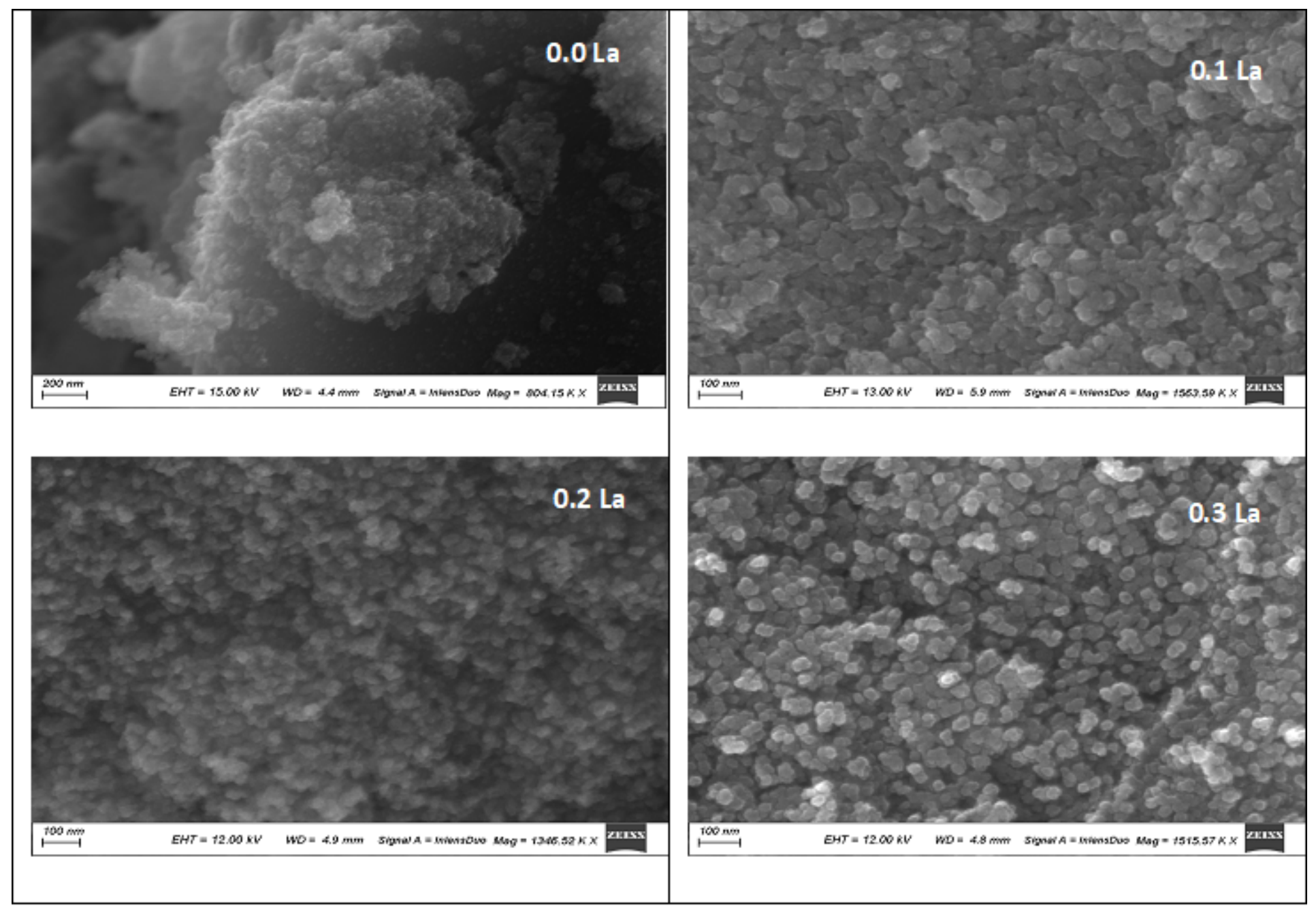

\section{Figure 4}

FESEM of Fe304nano-powders co-doped with Zn2+ ions and different La3+ ion molar ratio synthesized via co-precipitation route under $\mathrm{N} 2$ atmosphere and annealing at $800 \mathrm{oC}$ for $2 \mathrm{~h}$ 


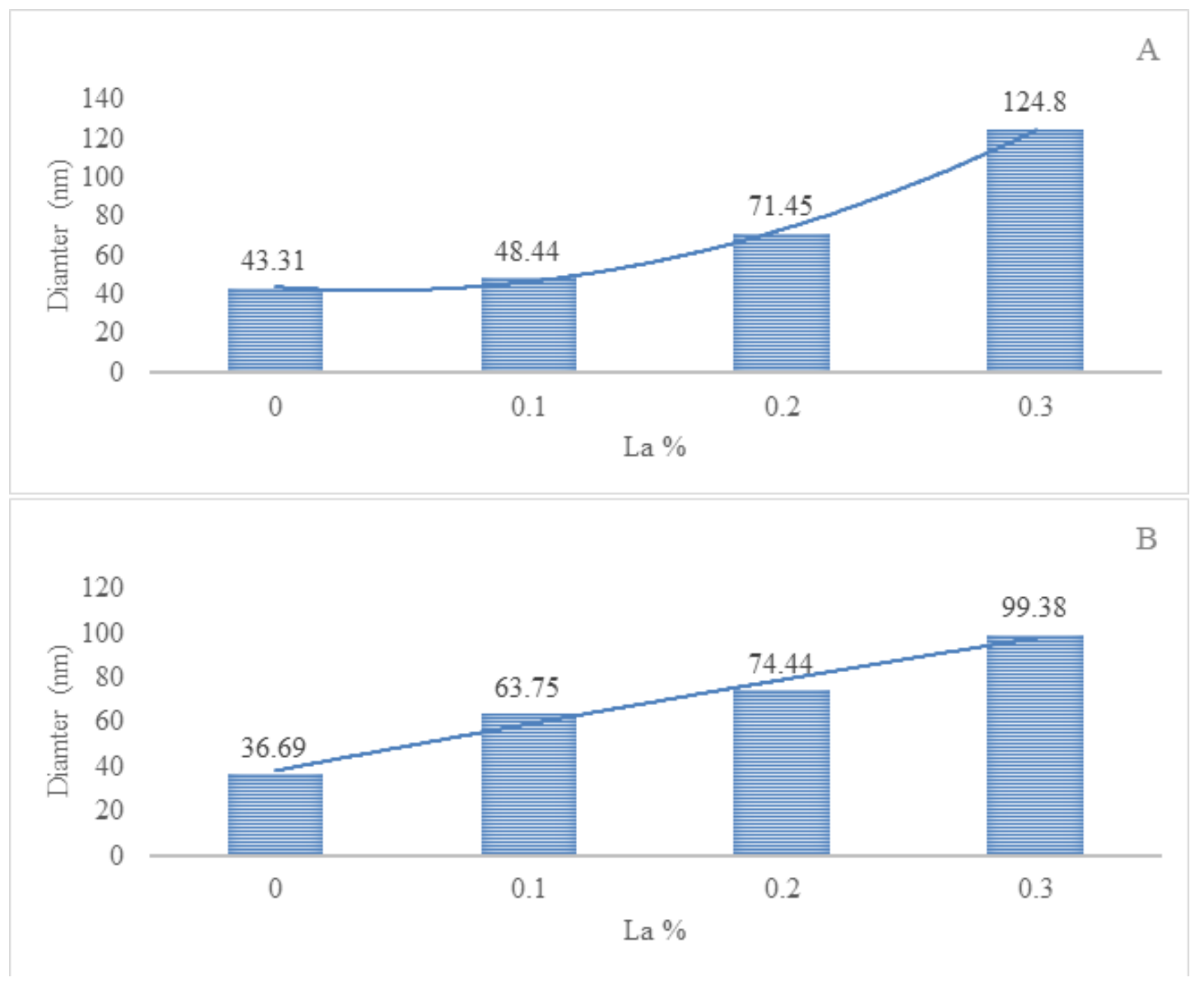

Figure 5

Size distribution of the magnetite nanoparticles at different calcinations atmospheres: (a) N2. (b) 02 

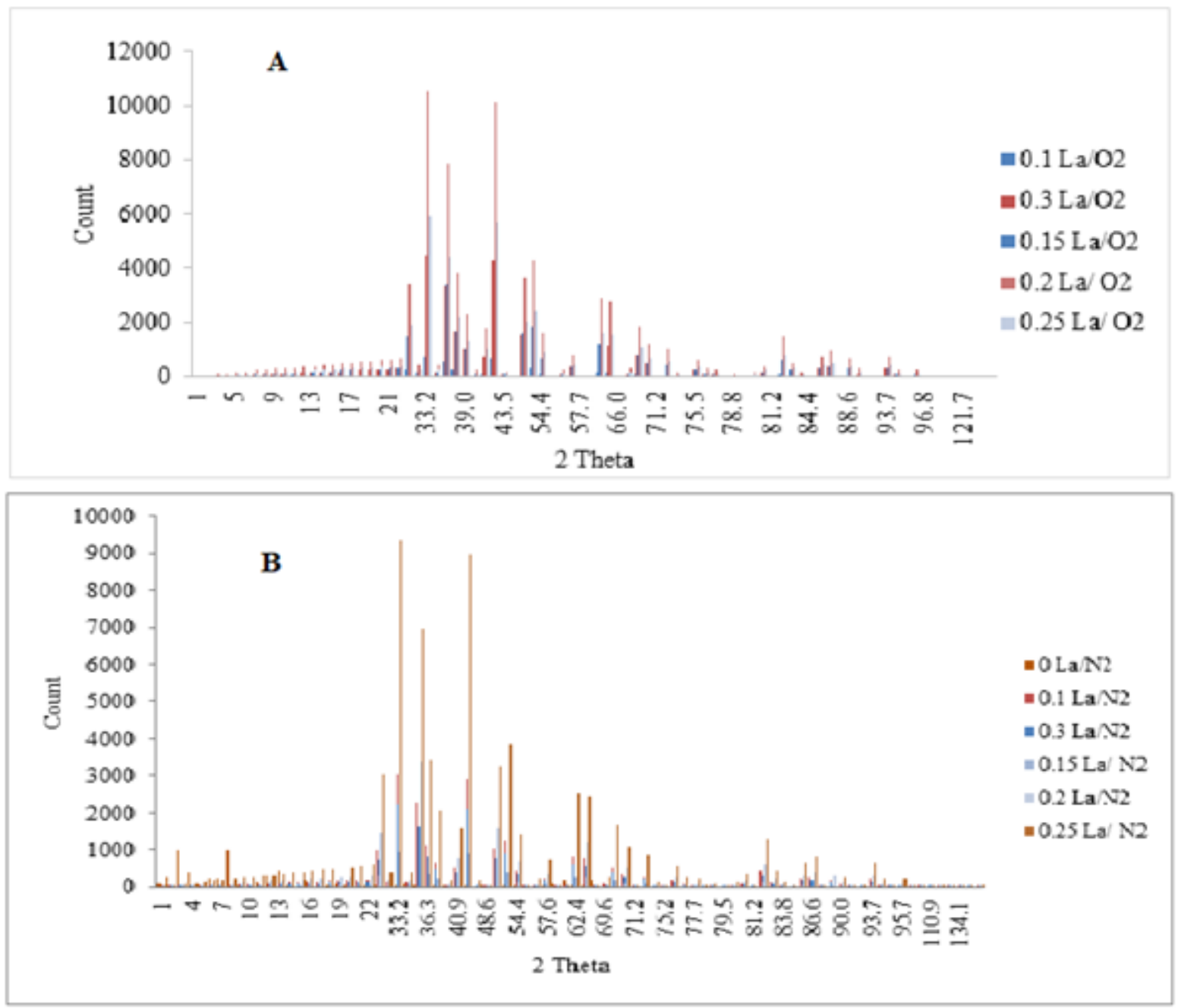

Figure 6

XRD patterns of Fe304nano-powders co-doped with Zn2+ ions and different La3+ ion molar ratio synthesized via co-precipitation route under A) 02 and B) N2atmosphere and annealing at 800 oC for $2 \mathrm{~h}$ 


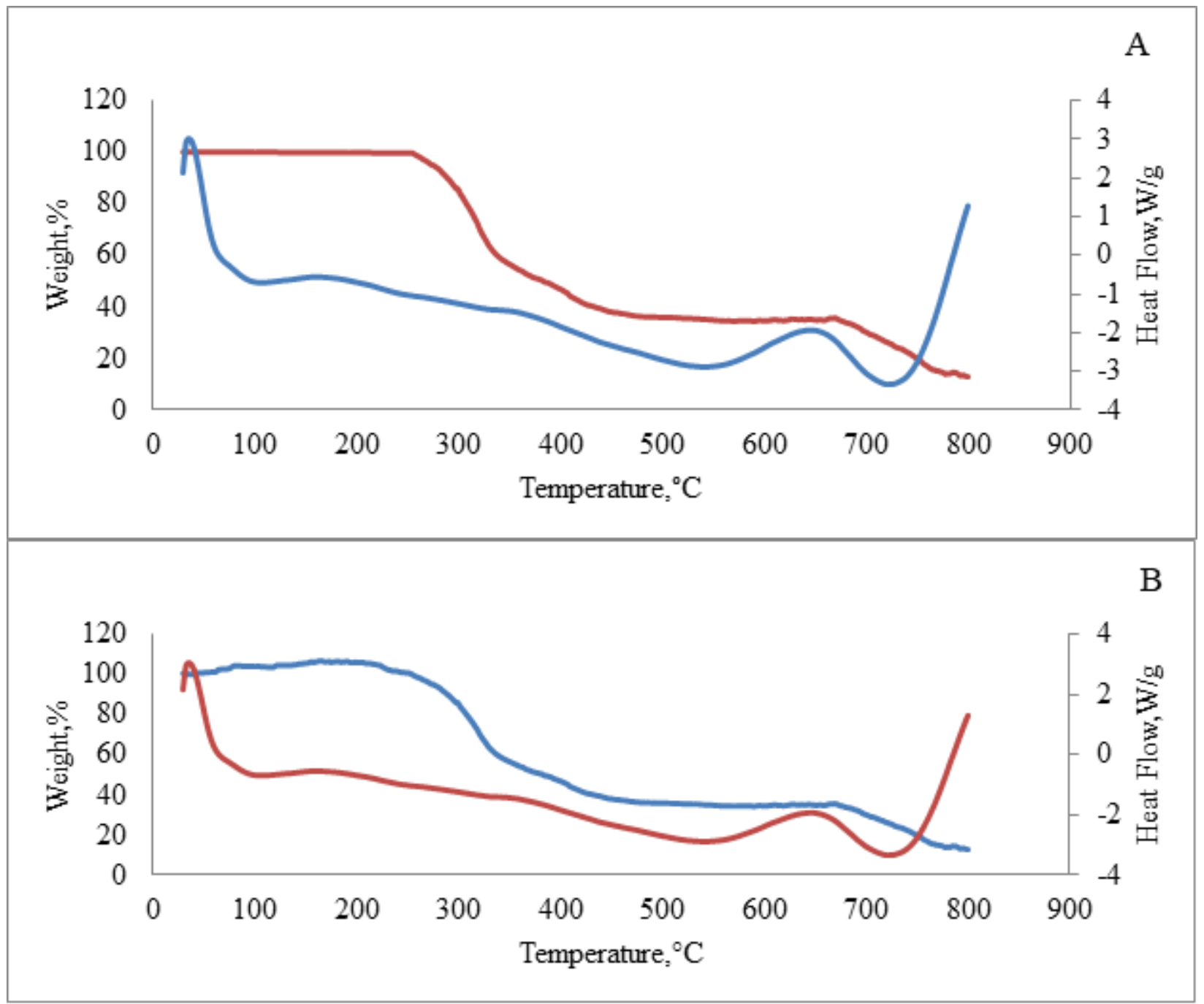

Figure 7

TGA and DSC analysis of $0.3 \mathrm{Zn} \mathrm{La(x)Fe(3-x)04calcinated} \mathrm{in} \mathrm{a)} \mathrm{N2} \mathrm{and} \mathrm{b)} 02$ atmosphere 


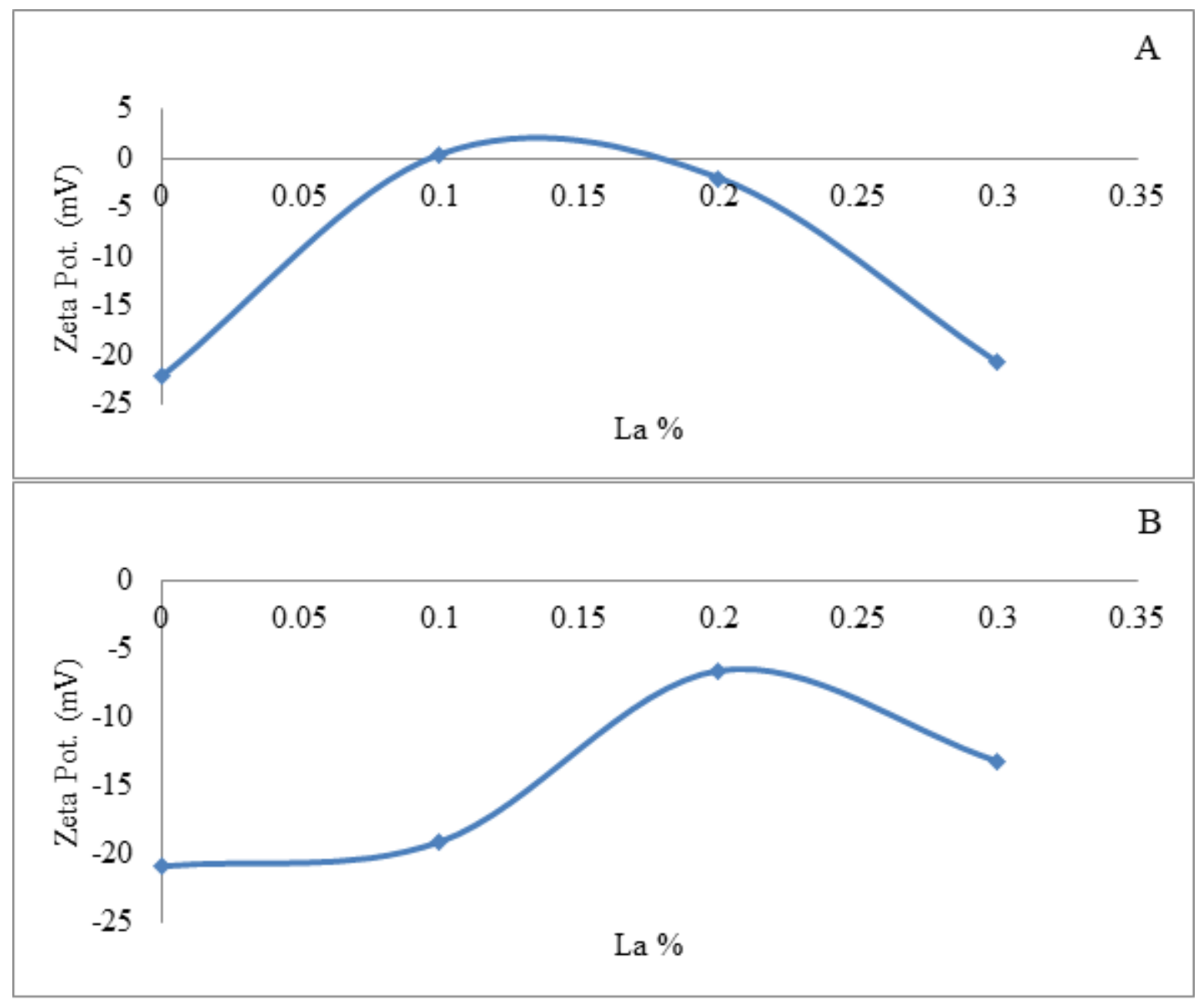

Figure 8

Zeta optional of $\mathrm{Zn} \mathrm{La}(\mathrm{x}) \mathrm{Fe}(3-\mathrm{x})$ O4NPs calcinated in A)N2 and B)O2 atmosphere 

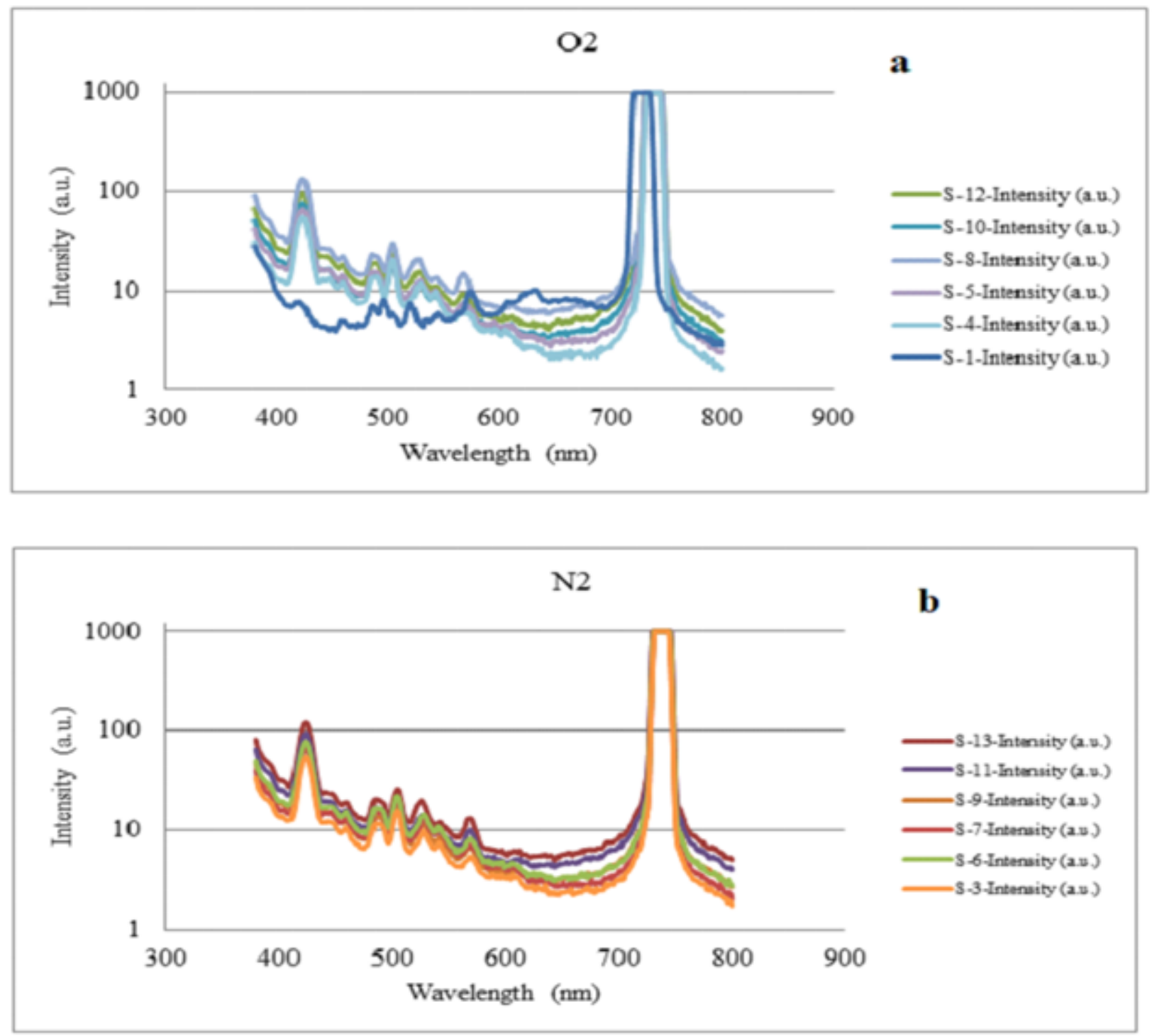

Figure 9

The photoluminescence (PL) spectra of the $\mathrm{ZnLa}(\mathrm{x}) \mathrm{Fe}(3-\mathrm{x}) \mathrm{O} 4$ at N2 and 02 calcinations conditions

Mean inhibition zone diameter of E. coli tre ated with nanoparticles

Number of bacterial colonies\%

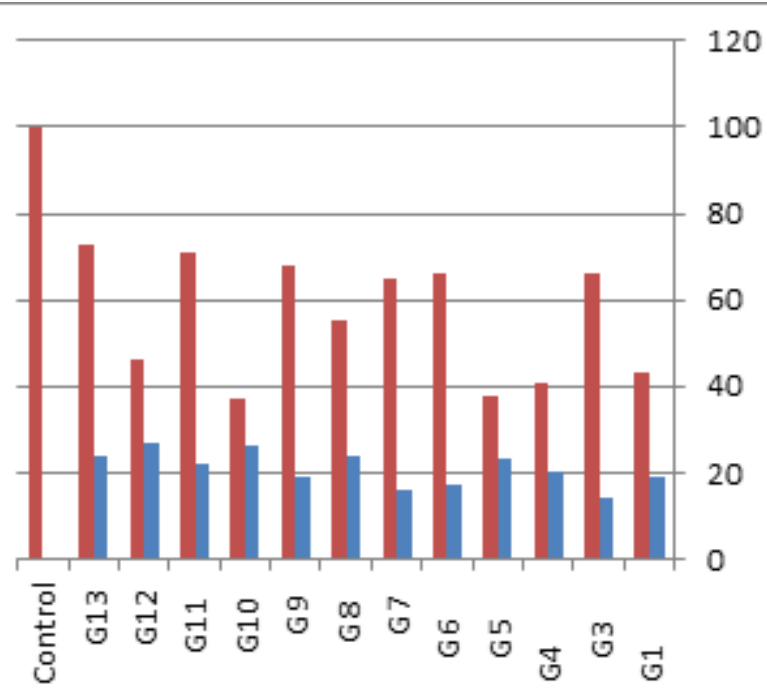


Figure 10

The diameter of inhibition zone of the studied bacteria at different concentrations of calcined ZnLa(x)Fe(3-x)04NPs at 800oC.
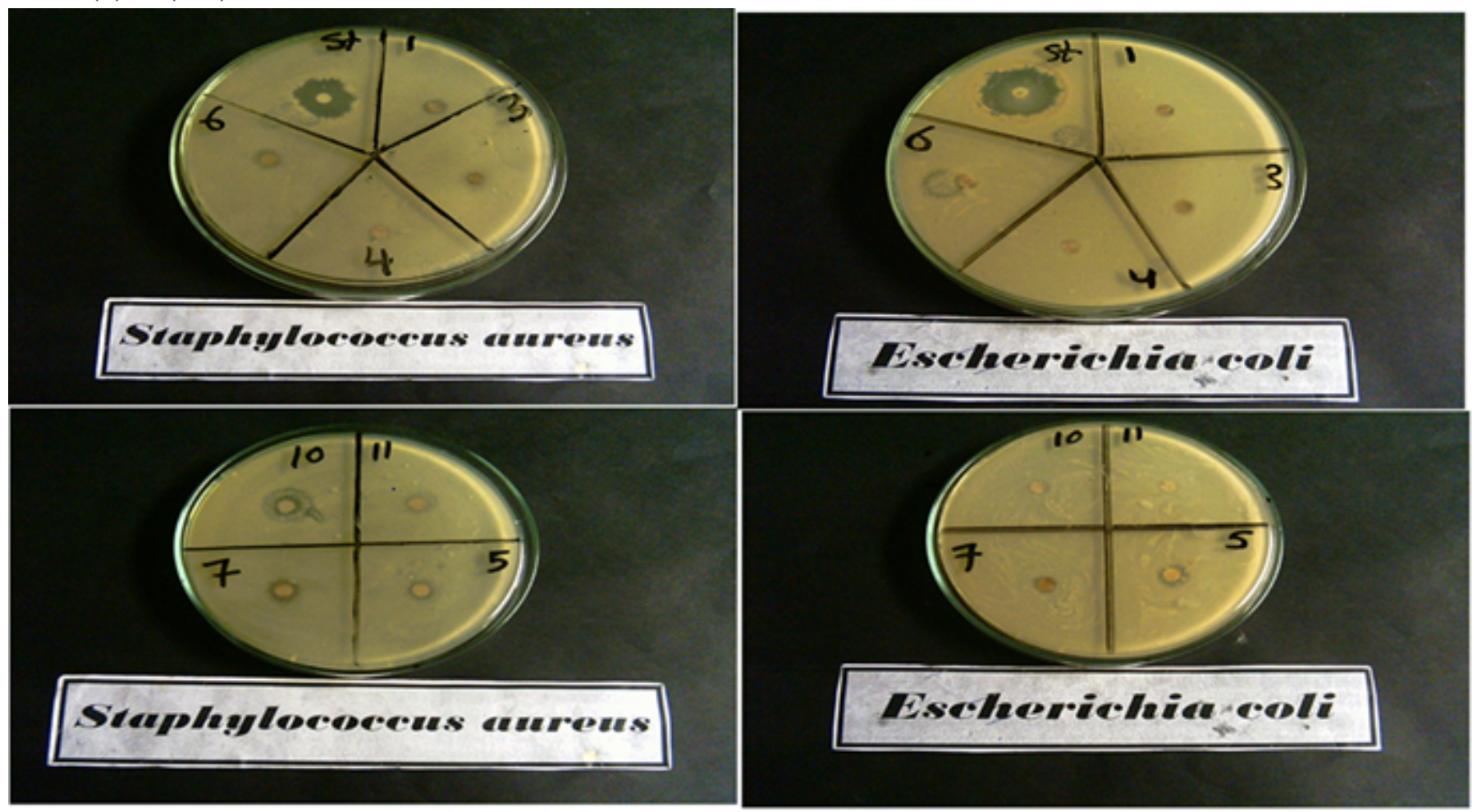

Figure 11

Antibacterial micro-dilution test of Zn La(x)Fe(3-x)04 NPs 